\section{景观与批评: \\ 可见与不可见的交错 \\ LANDSCAPE AND \\ CRITICISM: \\ THE CROSSING OF \\ VISIBLE AND INVISIBLE}

事实上, 批评意味着收集现象的历史精髓, 将它们严格地评价并 篮选, 展示它们的神秘、价值、矛盾和内在本质，并且探索它们的全 部意义 ${ }^{[1]}$ 。

从今以后, 唯有更执着的意愿才能让艺术和风景的轮廓再次鲜 活起来，恢复其往昔的荣耀，因为两者都脱离了日常的平叙和眼睛的 直觉，成为了计划、庆典、指导、督察、规范的对象, 为“景观规划 师” 和主持人所管 $[2]$

\section{1 景观与批评的理论思辨}

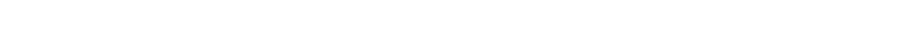
元超越 ${ }^{[3 \uparrow[5]}$ (图1)，也在于主客体之间错综复杂的关系 ${ }^{\circledR}$ ——现代欧洲 景观概念之发展表达了主体是科学客体演变的一种对立物, 它是视觉 性的、局部的, 与中国的山水思想有着根本的差别 ${ }^{[6[]]}$ (图2)。理论上 的思辨常常双重的悬置了景观的存在。借用伯纳德 - 罗素对于哲学与 哲学家之间关系的比喻, 景观好似一位外表热情而内心孤傲的女士， 只有依靠理性而又不失温情的双手才能触碰到她的内心, 即景观的表 象与本质、主体与客体之间的关系需要凭借批判性思维和批评的手段 进行阐释和认知 ${ }^{[8]}$ 。在此, 景观设计师一方面不知疲倦地借鉴或创造 出特定的概念以期“俘获芳心”，进而实现职业的自治；另一方面， 这个职业团体却不可避免地陷入概念建构与实践技艺的鸿沟之中 ${ }^{\circledR}$ 。本 文面对以上或隐或显的困境而提出追问：是否存在某种思维、某种手 段, 抑或某项特定活动——例如批评一一可通过风景园林师与景观之 间实现有效的对话来激发潜在的洞见, 从而提升专业实践的文化创造 力和想象力 ${ }^{[9-[12]}$ ?

在过去20余年里，尽管风景园林学领域内的理论探索大多是多 元的、离散的、浅尝轩止的, 且缺乏核心议题, 但不可否认的是, 这 些探索确实拓展了景观批评的深度和广度, 包括景观的过程性、事件 性、动态性和不确定性 ${ }^{[13]-[15] 。}$ 。举例而言, 景观都市主义既批判了审 美意义上的风景如画, 也批判了理性工具意义上的科学规划以及相关
https://doi.org/10.15302/J-LAF-20170602 收福时间 RECEIVED DATE / 2017-05-15 中图分类号/ TU98 文献标识码/A

\section{慕晓东}

清华大学风景园林硕士, 香港中文大学哲学硕士 (建筑学方向) 在读

香港中文大学建筑学院503室

xdmu@163.com
摘要

景观批评之于风景园林学在很大程度上是缺 失的, 此现状判断是本文写作的初衰。景观与批 评的理论思辨、景观批评缺失的历史性分析、设 计批评与阐释性批评的基本印象、景观设计批评 的操作, 以及批评家应该扮演的角色, 是本文论 述的主要内容。本文试图提供一种认识景观批评 的具体语境, 以增进人们对于这个被忽视议题的 理解。本文假设景观与批评之间的双向互动, 既 能够激发景观的文化想象力, 又能够促进景观空 间的社会效应, 还可以对风景园林学科产生一定 的积极作用。

\section{关键词}

景观; 批评; 历史; 理论; 文本写作; 视觉图像; 空间建造

\section{Xiaodong MU}

Master of Landscape Architecture, Tsinghua University Postgraduate of Mphil. in Architecture, The Chinese University of Hong Kong

\section{ABSTRACT}

With an intention to criticize the poor development of criticism in the discipline of Landscape Architecture, this paper will discuss six aspects of this topic: some theoretical speculations on landscape and criticism, historical investigations on its deficiency, a simulative panel of concrete landscape design criticism, various landscape criticism in different fields, three operations of criticism on landscape design, and the role what critics ought to play in this profession. The paper attempts to build a context that helps enhance professionals' understanding of landscape Architecture for decades, arguing that the interaction between landscape and criticism might stimulate the cultural imaginations of landscape, increase the social effect by landscape spaces, and partly promote the practical level of Landscape Architecture.

\section{KEY WORDS}

Landscape; Criticism; History; Theory; Textual Writing; Visual Image; Spatial Construction criticism, which has been neglected in Landscape

整理 田晓劼 王颖 张晶志

译 慕晓东 田乐 王颖 田晓劼

EDITED BY Xiaojie TIAN Ying WANG Jingrui ZHANG

TRANSLATED BY Xiaodong MU Tina TIAN Ying WANG Xiaojie TIAN 


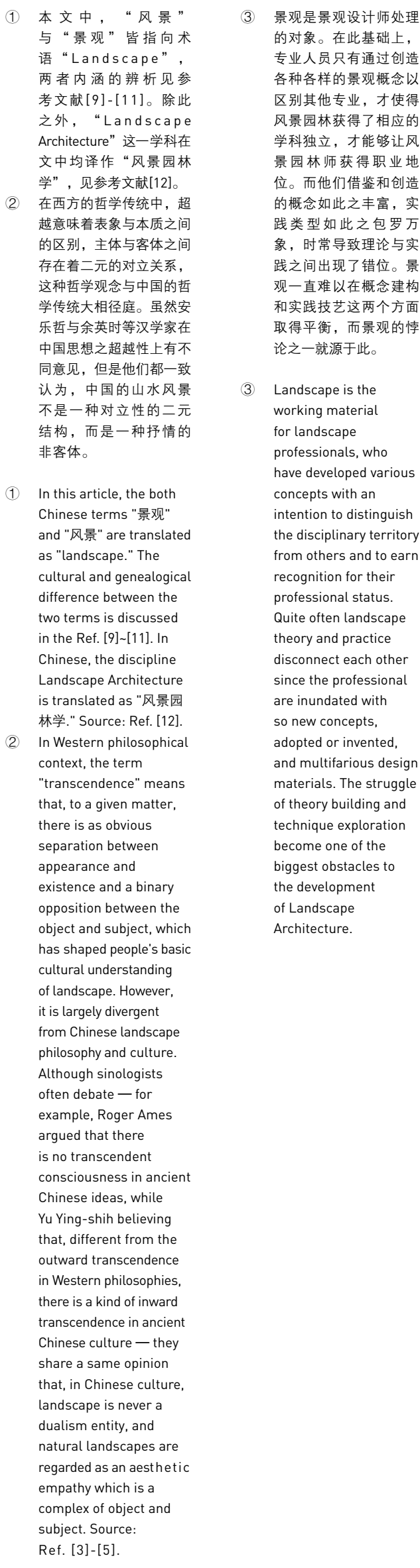
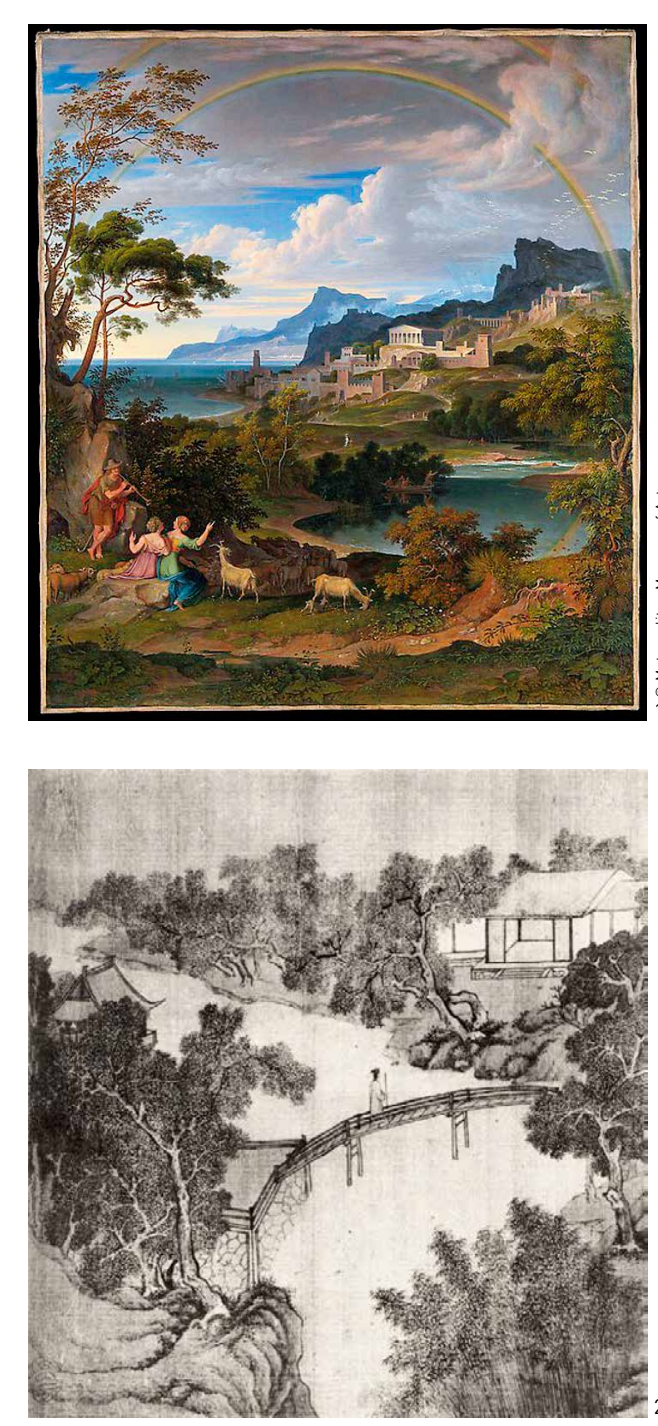

1. 约瑟夫.安东科赫.科赫绘 制的《带有彩虹的理想

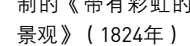
2. 等观》虹—出自文征明 《拙政园三十一景图》 ( 1533 年)。图片来 源: 参考文献[108]。
1. Heroic Landscape with Rainbow (1824), by Joseph Anton Koch. 2. The Small Flying Rainbow, Thirty-one Scrolls of Humble Administrator's Garden, by Zhengming Wen, 1533. Source: Ref. [108].
Criticism, in fact, means to catch the historical scent of phenomena, put them through the sieve of strict evaluations, show their mystifications, values, contradictions, and internal dialectics and explode their entire charge of meanings ${ }^{[1]}$.

From now on, a more devoted will is needed to revitalize the silhouette of art and landscape, and recover their past glory, because they both have interrupted and detached away from the ordinary life with prosaic narration and the instinct of eyes, which made them become the projects of planning, celebration, guidance, supervision and norm, and to be managed by landscape $\operatorname{architects}^{[2]}$.

\section{Speculations on Landscape and Criticism}

The most intriguing and confusing facet of landscape ${ }^{(1)}$ lies not only in its binary transcendence of appearance and existence ${ }^{[3] \sim[5]}$

(Fig. 1), but also in its complex relationships between subject and object, or inside and outside ${ }^{2}$ - the evolution of the concept of landscape in modern Europe demonstrates that subject is regarded as a counterpart of the objective evolution of science, and landscape is visually and partially perceived, which is essentially different from the ancient Chinese ideas of landscapes ${ }^{\left[{ }^{[6] 7]}\right.}$ (Fig. 2). However, landscape has been suspended by those conflicting theoretical strengths for a long time. The metaphor proposed by Bertrand Russell to explain the relationship between philosophy and philosophers can be employed here to recognize the appearance and existence of landscape: landscape is like an enthusiastic lady hallmarked with a cold aspect, who might only be touched by combination of both rational and emotional $\operatorname{mind}^{[8]}$. This derivative metaphor implies that the relationship between appearance and existence, and object and subject could only be interpreted and perceived by means of critical thinking and criticism. Landscape architects keep making efforts to learn from other fields and inventing concepts in order to explore the core of the discipline and the way of disciplinary independence, but, inevitably, they might bog down in the gap between theory (metaphysic) and practice (technique) ${ }^{3}$. Considering all these dilemmas, this paper explores a way - in form of thinking, approach, or activity (for example, criticism) - to generate an effective dialog between landscape and landscape architect, and to stimulate landscape architects' insight, as well as imagination and creativity in design practices ${ }^{[9] \sim[12]}$.

Although the theoretical studies in Landscape Architecture are usually regarded as superficial, fragmented, or uncritical efforts in the last two decades, an undeniable fact is that those explorations have extensively and substantively been intensified by virtue of landscape criticism, including the research on landscape process, 
的知识谱系。它通过在欧美后工业社会的城市需求与理论建构之间建 立相应的联系, 试图令此类批评既能够取得在学术脉络中的历史合法 性, 又可以在当代城市的危机中获得现实的正当性 ${ }^{[16]}$ 。对于景观都市 主义的种种回应, 既有赞许, 也有质疑。争议本无可厚非, 然而那些 针对该理论的批判大多不得要义, 批评者似乎不能认识到这样一种状 况: 景观既是一种可参与、可体验的物理空间（强调身体性，自下而 上）, 又是一种纯粹的概念性思考（强调总体性，自上而下），两者 总是处于难以辨析的双重交织之中 ${ }^{[17]}$ 。这表明景观在可感知与可思考之 间不仅存在无法弥合的张力，更存在无法彻底分离的拉力。

在视觉层面上, 景观随处可见; 在触觉层面上, 它时时可感。但 与同样可见可感的雨、露、阴、晴相比，景观的概念和意义总是显得

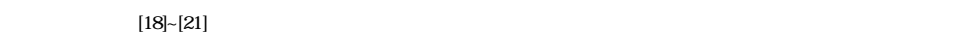
处凝视着主体身处的景观 ${ }^{\circledR[22]}$; 主体既存在于景观之中，又构成了景 观。因此, 景观总是摇摆于主体与客体之间 ${ }^{[23]}$ 。一方面, 我们在脑海 中主动建构了景观的意向性; 另一方面，我们又被动地构成了景观的 物质真实性。在物质意义上我们可以完全地占有景观，但它却只能停 留在诗人的想象之中。景观既充当了体验和生活的场所，又散发着某 种超体验的神秘气息, 让人产生一种似曾相识的感觉。倘若暂且不考 虑哲学意义上诸如表象论等观点, 一方面, 景观空间的真实性确切无 疑；另一方面，景观概念的建构性则又虚无缥飳。前者的显性与后者 的隐性之间具有一种内在性分裂和外在性融合的特点，这共同构成了 理解景观的首要前提一一类似地，文化批评家弗雷德里克·詹明信论 述了建筑总是处于现象学 (可感) 与意识形态 (建构) 的交织状态, 该论断能够为上述的阐释提供有力的间接证明 ${ }^{[24]}$ —然而这一特点经 常为专业学者所忽视，也加剧了人们对于当代景观的认知障碍。换言 之, 事实上景观自身存在着一种认知悖论，而批评的目的之一便是引 发论战、消除悖论，使得景观得以清哳地显现自身 ${ }^{[525][26]}$ 。

有趣的是，批评活动似乎也处于类似的悖论之中。批评的使命在 于在显而易见的题材和文字之中, 探寻隐藏在最深处的真知灼见, 其 任务并非描述和陈述事实, 而是通过细究、综合、建构、删除、矫正 和检测等方法分析相关文字、图像、符号和空间 ${ }^{[2]}$; 这是一项立足于文 本又脱离文本的理论建构行为 ${ }^{[28]}$ 。

与此同时, 批评还伴随着毁灭和重建的双重属性。特奥. 凡. 杜 斯伯格的先锋派声称人必须摧毁自己才能完成重建, 此宣言直接揭示 出批评的特定内涵。建筑史学家曼弗雷多. 塔夫里也认为批评一定是 以瓦解和拆散原有结构为起点的 ${ }^{[29]}$ 。先锋派运动破旧立新而后由新转 旧, 它的风靡源于摧毁了之前的历史基础, 它的失败在于被资本同化 dynamic, indeterminacy, and uncertainty ${ }^{[13] \sim[15]}$. For instance, landscape urbanism, which criticizes the aesthetic picturesqueness, scientific instrumentality and the related knowledge on hierarchy, attempts to make the criticism historically legitimate in the academic field and realistically valid in responding to contemporary urban crisis by integrating the demands of postindustrial cities with theoretical speculations ${ }^{[16]}$. The theories of landscape urbanism have received as much criticism as praise. However, most of the critical activities miss the point, might being resulted from the critics fail to realize that landscape is a complicated entity of both being a physical environment to be experienced in a bottom-up way and a concept based on intellectual thinkings while emphasizing top-down holism ${ }^{[17]}$. It has revealed that the dimensions of landscape between being physical and conceptual is always intertwined and irreconcilable.

Landscape is ubiquitous in the vision and tangible in tactile sense. Compared to these tangible natural phenomena, such as rain, fog, and wind, the concept and meaning of landscape, however, are not easy to be fathomed ${ }^{[18] \sim[21]}$. In a landscape, the subject might simultaneously observe and be observed ${ }^{\llbracket[22]}$, being not only part of the landscape, but also a part of landscape - that means a landscape can be understood as a synthesis of both subject and an object ${ }^{[23]}$. It implies that we actively conceive a landscape in our minds and passively constitute it in a physical way at the same time - though a landscape can be owned as a property, it only lives as poetic imaginations. Landscape is a place to experience and live, and always immerses a kind of mysterious quality that could invoke a sense of Déjà vu. Landscape is physically tangible while ideologically impalpable, if regardless of the philosophical discourse of presentationism. The visibility and the invisibility, or the explicitness and the implicitness together form a precondition for dispelling confusion on landscape - Similarly, cultural critic Fredric Jameson expounded that architecture is also a combination of phenomenology (being tangible) and ideology (being conceived $)^{[24]}-$ However, this core characteristic of landscape has been long-time ignored by the professionals that, in turn, has resulted in an impediment for people to comprehend contemporary landscape. In other words, the cognitive paradox in landscape has trapped the discipline itself down that can largely be eliminated by activities of criticism ${ }^{(525][26]}$.

What one of most interesting things is that this similar paradox parallels in criticism too. Criticism is an activity to reveal the truth of knowledge hidden behind the themes. To criticize is not to state well-known facts, but to probe, combine, organize, screen, rectify, and test the specific texts, images, symbols, spaces, and other relevant materials ${ }^{[27]}$. It is not only a theory-building approach based on knowledge, but also transcends those written texts ${ }^{[28]}$.
4) 源自市之琳《断章》中 的诗句 “你站在桥上看 风景，看风景的人在楼 风景, 看风景的人在楼 上看你。”见参考文献 [22]。

(5) 何为悖论? 法国现象 学家马里翁说过, “悖 论来自于可见之中的不 可见之干预……既在思 想中也在感觉中; 悖论 时常让人感到昡晕, 它 以一种特定的方式在思 以一种特定的方式在思 想上带来惊讶之感, 为 凝视提供震惊之感, 㤬 论远不能满足精神和身 体上的需求, 相反那种 多余的可见性损害了 它们。”见参考文献 [25]。

Quoted from the poem Part of Article, by Zhilin Bian, "When you are standing on a bridge to look at the landscape, and there is still a man who is standing on the tower to look at you." Source: Ref. [22].

5) What is a paradox? What is a paradox? Jean-Luc Marion
argued that the paradox is born from the intervention of invisible in the visible... in thought but also in sense; people might puzzle, surprise, or be shocked... far from bick... from being satisfied, neither physically nor mentally... fulfilling or satiating them... instead, being injured because of the visibility. Source: Ref. [25]. 
(6) 例如, 在建筑领域, 建 筑师阿尔多·罗西通过 类型学完成的建筑自主 型学完成的建筑自主 以及文丘里通过历史符 完成的意义回归, 都 是一种批判的行为。与 此类似的是, 在哲学领 域中, 利奥塔之于启蒙 时代的宏大叙事所建构 起来的知识的批判, 使 得微观叙事的后现代性 的知识形式 (包括差异 的知识形式 (包括差异 性、多样性和第盾性) 得以确立。几 [31][32]。

6) For example, in the field of architecture architect Aldo Rossi's study on autonomous typology and Venturi's typlogy and hypothesis on the recovery of meaning by the means of historical eclecticism can both be considered as criticism. In the field of philosophical and cultural theory, the criticism knowledge contributed by yotard, such as the difference, diversity, and incompatibility of criticism, is built thanks to the virtue of criticizing the metanarrative known from the age of enlightenment. Source: Ref. [31][32].
之后自身失去了内在的批判动力，从而变成了历史的一部分 ${ }^{[30]}$ 。因此, 批评不得不面对的一股神秘而又不可避免的力量，恰是历史。批评的 效力始于历史，也终于历史：一旦历史的洪流渐渐地侵蚀了批评的内 在力量，批评的创造力便会在这个过程中消耗殆尽，那么在已经成为历

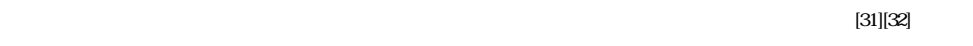
此，在各种显而易见的现实格局下，批评不断地凝视着历史背后的虚 空，尝试着摧毁原有的秩序，在不可见的历史深处重建某种可见的真 相，在辨析表象与真理差别的基础上实现一种具有判断价值的历史性 话语 (图3)

悖论同时渗透于景观与批评之中，但又略有不同：景观的悖论在 于概念上的不可见性藏匿于现实的可见性之中，这阻隔了人们对于景 观的窥探; 而批评的悖论是于可见性中归纳和演绎其不可见性, 这是 一种反向探索的流通。具有洞察力的批评能够有效拆解处于阻隔状态 的景观。在此，本文所讨论的景观批评是一种介于可见与不可见之间 的双重交错状态，澄清这种状态恰是针对景观谜团的解决策略。在这 个过程中, 景观批评的功能被视为一种增进认识的方式。景观形而上 的概念诉求、充满想象力的视觉图像系统与物质空间的真实营建，共 同构成了批评活动的三种操作路径。同时，它们也是认知景观批评的 基本出发点。在此之前, 简要分析景观批评相对匮乏的原因, 能够帮 助我们进一步加深对于景观批评的理解。

\section{2 景观批评的缺失}

无论从历史的存在状态进行判断，还是从当前的现实情况进行考 量，景观批评在整体上一直都处于相对被压制的境况。不过，若说景 观领域中不存在批评，也的确有失公允。在过去几十年，历史理论层 面上的意识形态批判，设计实践层面上的如画美学批判和形式批判，

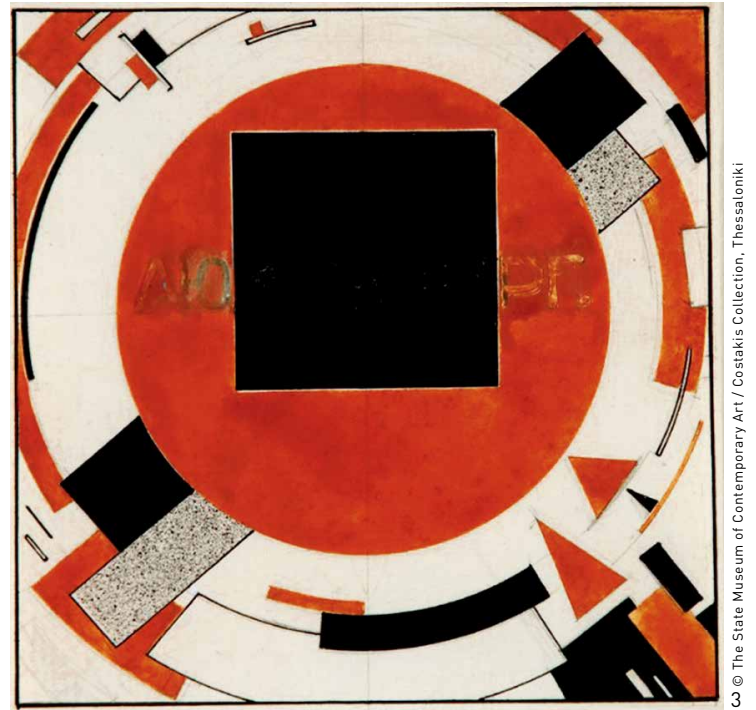

In the meanwhile, criticism also means to destruct the initial system and further reconstruct a new order. The avant-garde declaration advocated by Theo van Doesburg alleges that man must constantly destroy himself in order to construct himself all over again, which indicates the particular connotation of criticism. Architectural historian Manfredo Tafuri also argued that criticism starts with the destruction of the original structure ${ }^{[29]}$. The AvantGarde Movement has prevailed for a long period because of its standpoint as a counter to the corresponding historical foundation, and failed due to the loss of intrinsic motivations incited by original criticism after its complicity with capitalism, which has buried itself into the history ${ }^{[30]}$. Inevitably, criticism has been essentially influenced by the unfathomable hand of history. The effectiveness of criticism emerges from historical contextures and is finally effaced in this historical process: when a criticism loses its creativity, it would fade out in the history and become the target of a new round of criticism ${ }^{\circledR[31][32]}$. In this circumstance, criticism needs to explore the invisible truth hidden in the historical process by destructing the preexisting order, and to build an alternative discourse in historical genealogy (Fig. 3).

Paradoxical condition exists both in landscape and criticism, but they are in different manifested forms. The former is about disclosing the invisible concepts hidden in the visible realities, while the latter is about generalizing the invisible concepts from the visible facts. The former is an obstacle for decoding landscape, and the latter offers a contrary thinking, which could equip potentials to dismantle the opaque of landscape. This paper hypothesizes that landscape criticism is an intertwined complex of the visible and the invisible, an approach to unveil the puzzle of landscape, and a means to enhance people's cognition to landscape. Words, images, and physical spaces all provide an operative way and a starting point to conduct landscape criticism. Before elaborating those operations and related discussions, a detailed investigation on the deficiency of landscape criticism is necessary in this essay.

\section{The Absence of Landscape Criticism}

Although landscape criticism had, and still has been in an undeveloped predicament overall, it cannot be denied that there are a small number of criticism activities in the field of Landscape Architecture. The criticism on the ideological contemplation, formalism and picturesqueness of landscape has greatly influenced on the theoretical development and practical exploration in the past decades. For example, almost all the revolutions in Western modern Landscape Architecture started with criticizing picturesque aesthetics, some of which were from modernism against its static composition in the 1930s, from environmentalists against its 
都在景观领域发挥了关键作用。比如说欧美的现代景观设计史，几乎 每一次专业变革都是以批判如画审美为出发点: 在20世纪30年代, 现 代主义批判了如画的构图和形式; 60年代和70年代的环境主义者以生 存危机为由批判其内向的审美价值; 到了21世纪初, 景观都市主义者 则批判其感伤的、怀旧的、田园牧歌式的风景类型[33]。而且, 中国现代 风景园林学领域也存在着类似的批评意识和行为 ${ }^{[34)-36]}$ 。然而, 当我们 将关注的焦点从某些节点和细节转向学科整体, 就亟需用一种克制的 情绪来审视景观批评。究其缘由, 景观批评从未在真正意义上作为一 门独立的学科分支而存在过, 甚至关于批评思维的基本意识也极度缺 乏。景观设计师或批评家很少谈及景观批评的可能性和目的性, 也 极少反思主题的选择以及阐释议题的模式, 自反性在业内尚未形成 共识。

我们必须从历史、理论、实践和批评的复杂关系中理解景观批评 的当前格局。即便存在着“ 历史与批评完全无关” “实践可以与其地 域完全脱离” 等激进观点 ${ }^{[37]}$, 但总体来讲, 建筑、艺术和文学的历史、 理论、实践和批评之间总保持着紧密的关系, 并显露出“一荣俱荣,

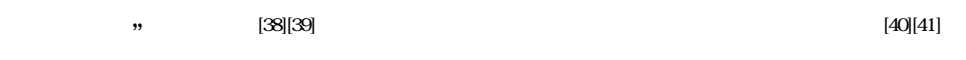
设计理论薄弱且分散 ${ }^{[[42]-[45]}$, 以及实践创新的不足, 皆是造成景观批评 缺失的直接原因。与此同时, 具有真知灼见的批评大多是经由相邻学 科生产, 再传递到风景园林学的知识体系中, 这种情况也间接造成了 景观批评的薄弱 ${ }^{[4]}$ 。

景观批评的萎摩现象不能全数归各于其自身的贏弱, 因为在风景 园林领域中，批评的部分缺失还可以归结于认识层面的误解。首先， 我们时常混淆景观批评的两种不同路径, 即设计层面的景观批评和阐 释性的景观批评一一前者的对象为利用测量、图绘等方法, 在较短的 时间中营造的景观; 后者则强调通过较长时间逐渐形成的自发性、生 产性和集体性景观，以及各种各样的再现媒介中的景观。其次，诸多 具有洞见性的景观研究成果并非出自设计批评, 而是源于现代主义绘 画、摄影、电影影像、文学作品、历史风景等阐释性批评，但是这部 分内容仍然没有引起风景园林学界的普遍重视。这一事实导致了两个 后果：一方面，我们混淆了景观批评实际上存在的两个维度；另一方 面, 又忽视了空间设计之外的批判性成果。这种似是而非的混乱状态 既导致了知识生产的界限含糊不清，又致使两者之间总不能实现双向 的知识互动和补足。这就是缘何当前大多数景观批评显得如此陈词监 sublime emotion in the 1960s and 1970s, and from landscape urbanists against the ameliorative, nostalgic and idyllic scenery at the beginning of the 21 st century ${ }^{[33]}$. Similar critical consciousness and activities have also gleamed in modern development of Landscape Architecture in China ${ }^{[34 \uparrow[36]}$. Nevertheless, when we shift our focus from those individual events onto the whole spectrum of the discipline, we cannot be very sanguine about landscape criticism, since landscape criticism has never been an independent subdiscipline and critical thinking has also been lacked for a long time in this very field. Landscape architects and landscape theorists rarely speculate possibilities and objectives of landscape criticism, nor re-examine their topics and genres. Selfreflection is also largely absented in the field.

The reason of the deficiency for landscape criticism should, and has to, be understood by clarifying the complicated relationship among history, theory, practice, and criticism. Although there are some radical arguments that history could be nothing to do with criticism, or design practice can also be completely detached from its surrounding milieu ${ }^{[37]}$, whereas generally speaking, those four facets usually interplay with each other in other domains, for instance, architecture, art and literature ${ }^{[38[39]}$. In this circumstance, the inadequacy of methodologies and substantial insights in landscape history ${ }^{[40]}$ ${ }^{[41]}$, the shallow and fragmented theoretical studies of landscape ${ }^{[[42] \sim[45]}$, and the lack of creative practices have all together resulted in the deficiency of landscape criticism. At the same time, the theoretical system of Landscape Architecture is mostly built by adopting knowledge and ideas from other related disciplines without any critical reflections ${ }^{[46]}$.

The underdevelopment of landscape criticism cannot be simply ascribed to its historical course, because the frustration resulted from our long-term neglect and incomprehension on landscape criticism could also deprive from the recognizant misunderstands in the field of landscape architecture. On one hand, there are two types of landscape criticism, including design criticism (on practice) and interpretation criticism (on textural hermeneutic), though their operational mechanisms are hard to differentiate. Criticism on landscape design emphasizes those built environment designed for construction in a short term, while the interpretation criticism refers to the productive and collective landscape with a lengthy period. And people are often caught into a kind of confused situation towards these two types of criticism. On the other hand, quite a lot of knowledge about landscape stemmed from criticisms on modernist painting, photography, films, literature and historical landscape has not been widely shared and assimilated in the field of Landscape Architecture, resulting in the lack of thought-provoking ideas, nor
(7) 历史研究与理论思辨之 间缺乏有效的转化, 也 是设计理论蒲弱的重要 是设计理论薄弱的重要 原因之一。例如, 为现 代建筑运动提供理论的 一个途径就是通过书写 现代建筑历史, 设计 活动的历史归纳和整 合就直接指向了某种 潜在的理论坐标, 见 参考文献[42]。

(7) The poor conversion from historical research into critical theory is considered as one of the main reasons for the weakness of landscape design theory. For example, some theories of modern architecture are derived from the historical writing and
historiography. Source: Ref. [42]. 
(8) Critical activities include the relevan discussions on the methodology of methodo of landscape criticism, source: Ref. [47]. som studies attempt to define and categorize the theoretical framework of landscape criticism, source: Ref. [48]. Furthermore, in the past decade, in the past decade, major publications China's Landscape Architecture, including Chinese Landscap Architecture, Landscape Architecture, and Landscape Architecture Frontiers, have showed their increasing interest in the issue of landscape criticism.

\section{调，且当前景观文化理论研究如此匮乏的原因之一。}

在认识到景观批评之历史缺失 (客观存在) 和认知错位（主观意

识）的事实之后，现实的需求能够进一步诱使相应话语的再生产。这 不仅仅是行业实践和知识探索的需要，更是社会文化和审美的诉求。 实际上，在中国研究领域中，零散的批评声音不绝于耳，而且近年来

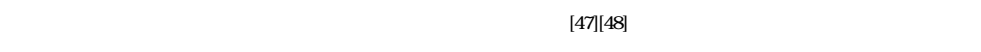
观批评的基本意识已蔚然成风，但相较于其他相邻学科而言，“批评 目前来说在风景园林学领域内尚且稚嫩”[49]。由此可见，在中文语境 中, 景观批评的宏观理论构建已经初具规模, 但是涉及具体的、高质 量的学术批评并未发展起来; 在英语的学术环境中, 以景观为议题的 批判性研究涉及各个学科且数量可观, 但景观批评研究既不热衷于理 论的总体建构 ${ }^{[50]}$, 也没有成为显学 ${ }^{[51]}$ 。鉴于此，倘若能够将景观历史、 理论、实践和批评视为一个整体，将景观批评之缺乏放置于四位一体 的基本观念下进行理解，那么就能有助于我们跳出单一的因果关系， 实现它们之间动态式的协同发展。

\section{3 关于景观设计批评的虚拟讨论}

在比较哲学的语境下，东西方知识传统之间的差别在于是否重视 事物之概念的精确界定 ${ }^{[22}$ 。在本文中，笔者不对景观批评做出定义，也 不试图做任何分析性论述，取而代之的是建构一个超越时空的、关于 特定景观设计的对谈场景。这场虚拟讨论的目的是通过具体的设计案 例，多角度地呈现景观设计的批评纬度（图4)。假设选择苏州博物馆 的中庭设计作为谈论的对象，对于参与其中的批评家而言，他们的言 论经“修饰和嫁接”后将直接表达某种既定的、独立的观点，并间接 暗示设计批评的特定维度。为了确保虚拟对谈场景的有效性，笔者对 每位发言人做了以下三条假设 : 其一，他们保持着各自思想的真实性 和独立性; 其二, 他们都曾经实地到访过苏州博物馆的中庭; 其三, 各位发言人讨论的目的并非为了达成某种共识, 而是以针锋相对的姿 态展开。 critical efforts. This is why the discourse of landscape criticism is prevailed with clichés and cultural speculation of landscape is also poorly developed in Landscape Architecture.

The awakening from long-term deficiency, coupled with the urgent demands in contemporary context, would stimulate the reproduction of discourse on landscape criticism, which is not only required for the professional practice and intellectual exploration, but also desired by the social culture and aesthetics. In fact, individual critical activities have never stopped in contemporary China, and the related theoretical framework of landscape criticism has started to be built in recent years ${ }^{\left[{ }^{[47][48]}\right.}$. And in the Western academia, the basic consciousness of landscape criticism has been widely received in landscape architecture, however, it is argued that criticism is still a young research field in Landscape Architecture ${ }^{[49]}$. In other words, some attempts on theoretical framework of landscape criticism have gradually emerged in China, while the concrete and detailed criticism on specific landscape design does not spring out to landscape architecture. Critical studies on landscape can be commonly found in other disciplines in English world, but few of them center on the establishment of a holistic theoretical framework ${ }^{[50]}$, and the thriving of landscape criticism has also been significantly impeded ${ }^{[51]}$. Herein, it is necessary to comprehend the absence of landscape criticism by regarding history, theory, practice, and criticism as a whole synthesis, which helps us eliminate the limitation of single causality and promises a dynamic future of the relevant theoretical development.

\section{A Simulative Panel of Criticism on Landscape Design}

In terms of comparative philosophy, Chinese knowledge system focuses less on defining something as a precise conception $^{[52]}$. Instead of defining or dissecting criticism on landscape design, this paper demonstrates the operation of landscape criticism through a criticizing scenario which imitates a dialogue among different critics on a concrete landscape project — the courtyard design of Suzhou Museum, by Ieoh Ming Pe. Beyond the scales of time and space, this simulation intends to gather a panel of various perspectives (Fig. 4). All the critics in this dialogue existed in the intellectual history whose original arguments are essentially remained with slight modifications or grafts for an explicit expression of the viewpoints. This dialogue is set with three premises: 1) the credibility and independency of each argument is guaranteed; 2) all of the critics have visited the courtyard of Suzhou Museum; and 3), the dialogue is to inspire and present diverse opinions, rather than seeking a common understanding. 


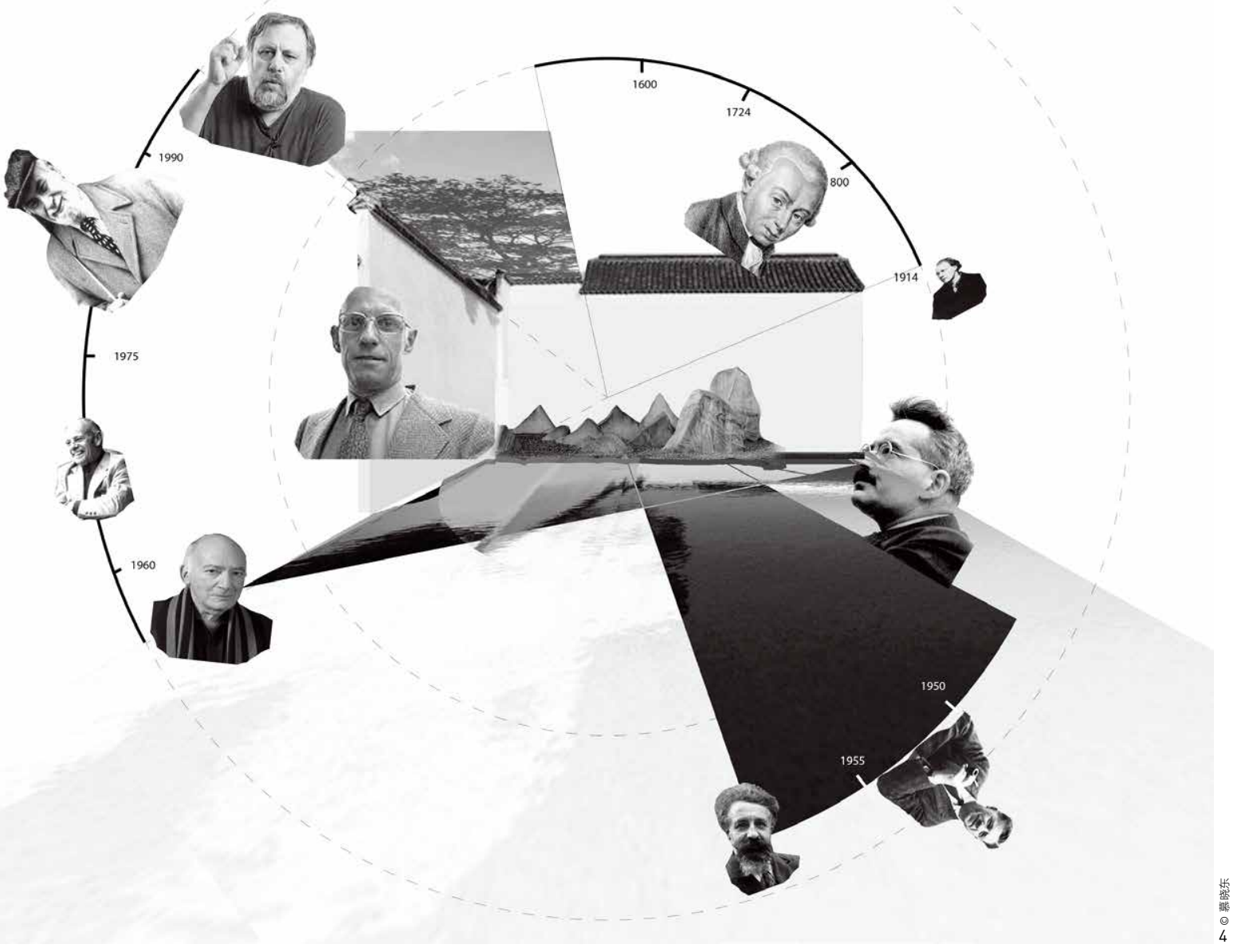
计的虚拟对谈场景。

4. On the simulation of criticism on the courtyard design of Suzhou Museum.

评论家A率先打破沉默，说道：“本人对设计本身没有任何兴趣， 但是对于“批评” 这一行为, 我始终有一个坚定的立场, 即无论各位 发表何种高见，每个人的观点都需要经过理性的审视。换句话说，每 一个针对该设计的批评都需要接受不断的再批评, 唯此, 它才能经受 住时间的考验。”[53]

正当大家还在若有所思的时候, 评论家B说道：“我赞同A提出的 前提, 但需要补充的是, 在进行任何批判活动之前, 我们都需要清楚 地认识到该批判是否具有一种功能性, 它能否内在地蕴含一种反抗的 艺术, 它是否是在与他者的关系中产生的。暂且不管庭院设计本身如 何, 至少从上述角度来讲, 关于它的批评应该是一种探究真理或未知 的手段和工具。”[54]

评论家 $\mathrm{C}$ 的思绪似平也被带动起来了：“景观批评要从空间、宇宙 世界、设计师和体验者4个方面进行探索，而这个庭院最终呈现出的空

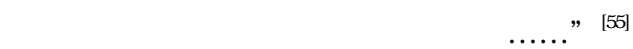

Critic A primarily breaks the silence, and speaks that "I have no interest in design, but I firmly believe that every incisive comment should not be escaped from the rational judgement. Saying, in order to be a tenable argument, every view (criticism as an outcome) towards this garden design should be constantly criticized by the critical thinking." ${ }^{[53]}$

Critic B seconds that "I totally agree with Critic A on the basis that we also need to have a clear awareness of the instrumental function, the spirit of resistance, and the interactive effectiveness of a critical activity before carrying it out. Regardless of the design itself, the criticism should be regarded as a tool to uncover the unknown truth." ${ }^{[54]}$

Critic C, who is inspired by the first two speakers, points out that "The criticism on landscape design needs to be examined from the four aspects of space, universe, designer, and user (or visitor). There is no doubt that the space should be the core of the whole criticism..." 
评论家 $\mathrm{D}$ 打断了 $\mathrm{C}$ 的发言，说道：“大家不必再故弄玄虚了，能 否说一些更为具体的内容？”D似乎显得有些不耐烦：“我从一开始 就认为这个设计没有任何价值。它的整体形式具有一种符号的意向， 一方面透露出一种强烈的历史感伤，另一方面暗示着一种具有反讽意 味的现代性。整个设计似乎希望通过破碎的符号来象征时间从过去到 某种未来的过渡，然而它所预设的未来只不过是一堆不断累加的残垣 断壁。”[56]

此时评论家 $\mathrm{E}$ 不以为然, 说道：“我不同意 $\mathrm{D}$ 的看法。我认为这 个庭院水池的折桥具有一种特殊的隐喻力量, 折桥的形式凭借着历史 的象征性关联将其意义传递出来。正是由于其与豫园九曲桥的形式相 似, 此庭院折桥的隐喻直接感染了我, 故而, 本人觉得这个庭院做得 很好。” [57]

当听到“历史”“隐喻” “象征形式” 等字眼时，F和 G目㮩间精神 抖擞，也不顾 $D$ 和 $E$ 所谈论的具体语境便直接争辩道 : “这个庭院设计 通过思考历史的传承和自身的文化坐标，有意识地探索了中国景观设 计的先锋性, 它的形式与内涵隐晦地弥合了古今之间的断层。至少从 这个角度来说，我坚持认为该设计具有极大的价值。” [58

但评论家 $\mathrm{H}$ 表示无法认同, 说道 : “景观批评与历史毫无关系, 它 不需要任何的生活经验和历史信息, 也不需要再现隐喻和象征, 它只 需要形式、色彩感和三维空间的知识就足够了。” ${ }^{[59]}$ 此时评论家」也随 声附和道：“一个艺术作品的审美判断产生于即刻体验当中。尽管我 不反对这种判断与观者自身的品味有关，但这种判断并非可以通过反 思形成, 或者说, 审美判断不需要历史的语境就能够得到反馈。” [60]

评论家K则反唇相讱：“诸位在理论思辨上看似无解可击，但是却 忽略了一个关键点: 批评不只凭借外部的理论框架以获得合法性, 它 还可以依靠真实的生活经验作为判断依据。苏州博物馆运用了一种流 动性很强的建筑形式, 其功能属性决定了这个设计必然会在很大程度 上削弱观者身体的感知, 这个庭院没有任何生活气息可言, 它架空了 时空的过程性体验, 一点儿也不动人。”[61]

评论家L则从另一个角度继续对该庭院进行抨击：“整个空间的闭 合和开放是以逻辑学家的思维设定的，假山、白色墙面和外围的树木
Critic D interrupts and declaims that "Let us stop talking about these enigmatic things, could we pay our attention to some concrete comments about this garden?" He obviously loses his patience, and continues to say: "Specifically, this piece of work means nothing to me from the very beginning. The form and structure of the garden shows an ambiguously symbolic image, which, on the one hand, strongly reveals historical sentiments and on the other hand, also indicates an ironic zeitgeist. Those fragmented symbols were designed to represent a progressive and continuous transition from the past towards the future, however, in my eyes, they are nothing but layers of ruins with simultaneous juxtaposition of past, present and future."

At that moment, Critic $\mathrm{E}$ argues in an indignant tone: "In my opinion, the zigzag bridge in the courtyard is very attractive, which resembles the Nine-Zigzag Bridge in Yu Garden in Shanghai, as a metaphor for the historic correlation of traditional Chinese gardens. To me, it is definitely an excellent design and I was deeply touched by this symbolic form." ${ }^{[57]}$

The terms, such as history, metaphor, and symbol, have provoked Critics F and G's nerve, who dispute, disregarding the conversation context, that "By merging its historical inheritance and cultural reconstruction, the garden can be seen as an avantgardism effort which bridges the gap between traditional garden and contemporary landscape with an ingeniously implicit design. In this vein, I believe that this design is of great value." ${ }^{[58]}$

With a strong disagreement, Critic H clamors that "History (or metaphor) has nothing to do with the criticism on landscape design; design criticism depends upon the knowledge of form, color, and spatial layout of the courtyard, rather than on life experience, historical information, memory or metaphors." ${ }^{[59]}$ His argument is echoed by Critic J, who explains that "Aesthetically, the garden needs to be commented by visiting it, and our evaluation would be generated from the immediate intuition. It cannot be denied that everyone's aesthetic preference partly varies and matters on rest with individual taste, however, I do believe that the aesthetic verdict is neither a result of contemplation nor a reflective thinking on history." ${ }^{[60]}$

Critic K beings with a sarcasm, "Brilliant arguments! However, all of you missed a key point that the legitimation of the criticism on landscape design is not only based on the externally theoretical framework, but also on internally real life experience. The architectural form of the Suzhou Museum was designed for mobility, which unavoidably would detach visitors' bodily experiences from their ordinary life. The courtyard looks like lifeless and uninviting; it fails to provide any memory experience of spatial and temporal changes."[61]

Critic L continues to criticize the design that "Seemingly the 
之间毫无渗透性，园内与园外之间呈现出相互排斥的关系。相对于用 一种隐喻的方式去赋予内在空间以诗意和想象而言, 这个设计在空间 的内外关系上呈现出的是纯粹的几何性, 它们之间甚至带有某种对立 氛围，我感受不到任何平静。”[62]

整场谈论顿时热闹了起来，大家争先恐后抛出论调：“庭院内墙 里的假山颇有古人三远法之笔意, 同时又能显露出静模绘画与动游空 间的本质差别” [63]“整个庭院的设计几乎摒弃了偶然性和不确定性，处 处彰显着乌托邦的痕迹” “苏州博物馆的几何形式打破了庭院空间的 模糊性” $1 . . . .$. 讨论的气氛越来越热烈，大家各抒己见，相互争辩。忽 然, 评论家M站了起来, 凝视着整个庭院, 意味深长地说道: “景观批 评本身就是一种视差之间，它们之间的阐释差异是不可避免的。不同 的人所接受的教育、自身经验和文化格调皆不同，所以他们各自关于 特定景观的评价必然不同。若是没有此类辩证思维, 再多的争议也都 无效。” ${ }^{664}$ 虽然不少评论者仍觉意犹未尽, 但这句总结性的发言让此次 讨论以绝对沉默的方式结束了。

倘若以非黑即白的标准来评判此次虚拟讨论, 便背离了构建这 个场景的初衷。在整个过程中，我们获得了一些对景观批评的基本印 象, 也感受到了诸多设计批评的痕迹。首先, 倘若承认真理具有多元 性, 那么存在多少个理论立场和现实出发点, 就可能存在多少种景观 批评。争论的意义并非在于提供唯一的、排他的答案, 而是为了呈现 一种多元并存的智识状态, 这是认识景观批评的一个基本前提 ${ }^{[65]}$ 。其 次, 景观批评必须在特定的知识路径中展开, 清楚地界定景观批评的 理论立场、现实意义、价值判断等因素, 能够有效避免批评活动陷入 “对牛弹琴”的滥加境地。第三, 批评的目标之一是为了部分增进对 于景观的既定认知, 并且发掘景观的内在潜力。除此之外, 评论家还 应该谨慎地选择景观批评的支点, 严谨地演绎整个批评过程, 精心地 维护批评对于时代危机的针对性和有效性 ${ }^{[66]}$ 。 enclosure and unfolding of the whole garden was designed with a strict logic, and there is no permeability and interaction between the inside and the outside, which could be seen from the layout of rockery and white walls with the trees in the surrounding. With less poetry or cultural imagination, the spatial design shows a pure geometric choreography and a sense of mutual exclusion where I could hardly feel tranquility." ${ }^{,[62]}$

All the critics start to engage into the debate, and arguments include "The rockery located between the bank of pond and the enclosed wall of courtyard was designed under the principles of traditional Chinese landscape painting - three types of farness: in height, in depth, and in distance - which also reveals the essential distinction between static painting and dynamic space." "63] "The design draws a picture of Utopia that represses the possibility of unexpected or potential events."(9) And, "the geometrical and hard form of the museum disturbs the ambiguity and vagueness of spatial atmosphere in the whole garden.” (1) This fierce discussion continues without that anyone could be convinced by others. All of a sudden, Critic M concludes that "Essentially, the understanding of landscape is built on the ineluctable gap of parallax, which varies due to the different educational background, life experience, and cultural preference of the commentators. Without this dialectical thinking, even more radical debates would not shed light on the essential interpretation on this garden by criticism." ${ }^{[64]}$ The conversation ends up in the way of absolute silence, though some critics still want to finish their speeches.

We cannot evaluate this imaginative dialogue with a right-or-wrong and dichotomous thinking. In this panel, the conversation is to outline a profile of criticism on a concrete landscape design and to demonstrate some detailed operations. First, genuine knowledge offers us multiple possibilities to interpret and understand it, which means different standing points would result in different critical thoughts on landscape design, theoretically and practically. Again, the disputation is not to seek for some unique or exclusive answers, but to provide an opportunity to explore diverse knowledge, which is one of the primary preconditions of landscape criticism ${ }^{[65]}$. Secondly, the theoretical ground, practical significance, and evaluation criterion should be clarified in order to avoid meaningless contention. Thirdly, one of the objectives of criticism on landscape is to enhance people's cognition on specific design and to excavate its potential dimensions. In addition, critics need to prudently choose their standing points, carefully organize the structure of their critical statements, and maintain the effectiveness of criticism towards the serious issues of our times ${ }^{[6]}$.
(9) 此观点由清华大学建筑 学院建筑评论课上周榕 教授的观点整理而成。 教授的观点整理而成。 此观点由香港中文大学 建筑学院的冯仕达教授 在2015年游历苏州博物 馆时, 谈及庭院与整体 建筑之间的关系的观点 整理而成。

(9) This view is derived from the lecture given by Rong Zhou, professor in the School of Architecture, Tsinghua University, rehearsed with the author's words.

(10) This view is derived from the conversation between the author and Stanislaus Fung, professor in the Sch of Architecture, The Chinese University of Hong Kong, when they were visiting the Suzhou Museum in 2015. 


\section{4 景观批评的维度}

前文试图表明作为一种设计实践的景观与具体的批评的关系，本 章节将讨论景观作为一个“更广意义上的文本”与批评的关系。“景 观是一种真实的存在”或“景观只是一种表象、幻象”，此两种观点 成为了形而上学与后现代主义争论的焦点。前者的理论基础在于景观 的表象背后存在一个真实的本体; 而后者则假设表象的背后不涉及任 何的实在性。在后现代主义的语境中, 所有事物都呈现出表面性, 表 象之外再无实在，也没有任何的神秘性等待着被挖掘 ${ }^{[6]}$ 。康德认为“物 自体的存在导致了我们无法完全认知世界”，这种观点使得景观的后 现代主义追问部分地变成了建构主义。后现代主义与建构主义的共性 在于, 它们都假设不存在真正的事实, 世界和认知本身都是通过各种 写作、话语或科学方式建构起来的 ${ }^{[68]}$ 。在此前提下, 景观就变成了通过 各种思维和方法被建构成某些特定的认知。故而, 对于景观的阐释不 在于——也不可能——彻底解决本体论的疑虑, 而在于在批评的语境 中为我们提供某种深度理解景观理论的模型。

关于景观的意识形态批评，丹尼斯- 科斯格罗夫提供了两种相应 的思考路径。一方面，“景观不再是一个能够通过纠正技术、理论或 者思想而恢复其原真意义的重写本，它更像是显示屏中不断增加篇幅 的文本, 只要轻触回车键, 景观的意义就会被创造、延展和改变, 甚 至最终还能被一键删除” [69[7ㅇ]。在后现代主义的视角下，景观的意义不 再稳定，这与现代主义语境中的宏大叙事、一价真理和稳定意义截然 不同，后现代主义的景观阐释直接完成了批评并颠覆了现代主义景观 意义的系统。另一方面, 科斯格罗夫在马克思主义的研究视角下诠释 了景观的概念, 将其视为一种观看方式,一种经济社会史下的产物, 一种拥有自身表达技术的文化实践 ${ }^{[7]}$ 。该论点在20世纪80年代颇为新 颖, 若以历史研究为参考标准, 那么从一开始, 科斯格罗夫的写作本 身就有意识地蕴含了批判的动机。正如他在20年之后回顾道 : 当时的 写作目标就是为了突破景观总是隶属于设计和品位的这一解释系统 ${ }^{[72]}$ 值得玩味的是，科斯格罗夫的研究对象虽是西欧景观史，但其批判却 可以直接指向了风景园林学领域的实践和现状。换言之, 西欧的景观

\section{Dimensions of Criticism on Landscape and the Related Representation}

The above statements have tried to demonstrate the relationship between landscape design and detailed criticizing activity. This section attempts to clarify the complicated relationship between landscape, as a readable text in a broader meaning, and criticism. Metaphysically, the arguments that explore landscape is whether a real entity or not, or landscape is a kind of appearance or illusion, have been one of the substantial disputes between metaphysics and postmodernism. The former is developed on the hypothesis that there is always an ontological reality constituting and transcending the appearance of a landscape, while the latter contending that "everything is an image... there is no ontological realities hiding within, nor mystification to be unveiled." ${ }^{[67]}$ Immanuel Kant's view that the thing-it-self results in our inabilities in cognizing the world has further conformed the postmodernism of landscape and considers it as a kind of constructivism. In constructivism, the universe and our knowing are organized and constructed by written languages, discourses, or scientific interventions ${ }^{[68]}$, implying that landscape is also organized and constructed with specific thoughts and methods. Thus, to interpret landscape is not — or impossibly to respond to the ontological issues; instead, it can provide some theoretical models for deeper understanding of landscape by criticism.

For instance, the ideological criticism on built landscape proposed by Denis Cosgrove offers two trajectories of critical thinking. On one hand, "landscape seems less like a palimpsest whose 'real' or 'authentic' meaning can somehow be recovered with the correct techniques, theories, or ideologies, than a flicking text displayed on the word-processor screen whose meaning can be created, extended, altered, elaborated, and finally obliterated by the merest touch of a button. ${ }^{\text {"69][70] }}$ From the perspective of postmodernism, landscape no longer means a stable system, which has radically criticized and completely reversed the interpretation of landscape in a modernist sense that celebrates grand narrative, one-fold truth, and stable meaning. On the other hand, Cosgrove also considered landscape "as a construction, a composition of that world. Landscape is a way of seeing the world... within a progressive debate about society and culture" and "an ideological concept" from a perspective of Marxism ${ }^{[71]}$. Its conceptual rebellion against picturesque aesthetics was an active criticism towards the preconceived idea until the 1980s. As Cosgrove reviewed his own monograph twenty years later, he said that: "my original aim was to extend the scope of landscape beyond a prevailing narrow focus on 
和中国的景观并非毫无交集, 它们之间常常隐藏着不易察觉的、内在 的、相互作用的关系。有时, 看似完全不相关的景观阐释的立足点恰是 规划设计活动，而有时通过批判行为获取的实践合法性的基础正来自于 在文本阐释中渗透的理论模型。

现代性具有双重面孔。19世纪的知识分子，例如歌德和马克思， 他们总是在危机和机遇的双重语境下讨论现代文化和社会。但到了20世 纪, 马尔斯·韦伯和乔格. 西美尔等学者则坚定地选取了其中的一个面 向, 他们几乎抛弃了现代性的积极面, 彼时, 批判现代性便成为了世纪 之初的主流思潮 ${ }^{[73]}$ 。与此同时, 当其反馈到建筑和风景园林学领域时, 现代性批判的焦点转变成了对乌托邦、同质化和等级制度等思想的批 判，因为这些理念全面控制了空间营建的思维方式。面对这种禁欲主义 的建筑形式, 现象学和批判地域主义等思潮不断以批判的姿态登上历史 的舞台。其中，约翰·布林克霍夫·杰克逊的乡土景观直接指向了反对 纯粹几何形式审美的历史主义、文脉主义和地域主义 ${ }^{[74]}$ 。虽然杰克逊的 景观研究带有明显的非理论化倾向，但是他通过“将个人体验重新带回 到景观结构的解释框架” 以及“场所感知” 的方式 ${ }^{[75]}$, 一方面直接启发 了美国学术界对于景观批评的现象学研究 ${ }^{[76]}$, 另一方面也间接带动了风 景园林学领域的意义回归 ${ }^{[77][78]}$ 。与科斯格罗夫类似, 杰克逊也为景观批 评提供了一套范例式的参考。

基于以上论述, 景观研究的两大主流思潮, 即意识形态批评和现 象学批评, 皆由批评行为和批判性思维获取, 并且其关注点可以归结为 主体是否存在于景观之中。在论述新实在论时，德国哲学家马库斯·加 布里埃尔所言：“世界并不存在。”若我们将句中的“世界”改为“景 观” , 即景观并不存在。这个论断所蕴含的事实是其他所有事物都是存 在的, 唯有一个事物不存在, 即景观。我们或许能够通过批评的方式发 展出新的景观阐释, 而这一阐释最终便是一种景观批评。首先, 建构主 义视角下的景观概念侧重于排斥主体的主动参与, 现象学意义上的景 design and taste, and to broaden the connotation of landscape itself." ${ }^{[72]}$ It is interesting that Cosgrove's inspiring conclusion on the history of European landscape can be borrowed as a critical reflection on the development of Landscape Architecture. In other words, those two different types of landscape design do not never intersect; they interact in a subtle way. Ironically, one of most potential treasure-houses for design criticism is exactly offered by the theoretical narrations that are seemingly unrelated and independent with Landscape Architecture.

Modernity wears twofold masks. Intellectuals in the 19th century, such as Johann Wolfgang von Goethe and Karl Marx, had studied modern society and culture under a background of crises and opportunities; in the 20th century, Marx Weber and Georg Simmel inclined to deny the positive significance of modern technology and industry. Those criticisms towards modernity became one of the most prevailing ideologies in the early 20th century ${ }^{[73]}$, and transited into the fields of Architecture and Landscape Architecture until the middle of the 20th century, towards the notions of Utopia, homogeneity, hierarchy, and other thoughts dominating in the construction of physical space. Then, phenomenology and critical regionalism emerged as a critical force on rationalism and scientism. Among them, vernacular landscape advocated by John Brinckerhoff Jackson straightforward opposed the aesthetics of pure geometrical forms with resource to historicism, contextualism, and regionalism ${ }^{[74]}$. Although it cannot be denied that Jackson's landscape study showed a tendency of non-theoretical speculation, by bringing the individual experience back to interpretive structure of landscape and emphasizing the sense of place ${ }^{[75]}$, his writings directly invoked the phenomenological study of landscape criticism in American academia ${ }^{[76]}$, and greatly promoted the substantive re-exploration in Landscape Architecture ${ }^{[77][78]}$. Similar with Cosgrove's achievement, Jackson's academic contribution also provided an operative reference for landscape criticism.

Both ideological and phenomenological criticism, two major trends of landscape studies, are established upon the basis of critical thinking and criticism, and share a same research interest: Is the subject present or absent in a landscape? In the discourse of New Realism, if we understand the world as a landscape, it can be concluded as what German philosopher Markus Gabriel argued, "the landscape (world) does not exist entails that everything else exists... everything exists except one thing, landscape (world)." In this sense, criticism might offer us a new possible way to interpret landscape. First, ideological study excludes subject's intervention in landscape, while phenomenological study focusing on subject's experience and engagement. In New Realism, subject is a part of landscape, 
观则强调主体的体验性和能动性。而在新实在论的语境下，景观既有 主体的参与, 又并非只包含主体一一新实在论强调景观的主体和客体 之间既相互独立, 又保持双向互动的关系。其次, 景观的整体性不是 由局部集合拼凑起来的，虽然根据康德“作为先验理念的世界不可认 知” 这一理论基础，景观在整体上是不存在的，但作为局部的景观却 是确切存在的，例如街头绿地、公园小径等。这就是为什么景观在整 体上不存在而在局部却处处存在的原因。这种局部小景观凭借着“其 自在所是的状态” 能够具有各自的意义领域 ${ }^{[79}$ 。

依据新实在论的内在批判性，首先，景观在整体上不必获得一个 稳定的意义，与此同时，作为局部的景观又能保证其自身的确切存在 和意义。这种悖论既能够在一定程度上避免极端理性主义者的总体化 倾向，又能够缓解法国后现代哲学中取消意义的危机。其次，它有可 能提示了未来风景园林规划设计的潜力: 如果景观不再具有再现性, 并且回归到本身的存在, 那么或许我们可以从客体本体论的当代哲学 思潮中获得某种积极的回应 ${ }^{[80]}$, 抑或从景观的自主性和抵抗性的层面进 行进一步探索。

景观批评不仅可以发生于自身的知识谱系，还能充当一种外部阐 释的工具。景观批评完全可以超越其自身的解释范畴，涵盖艺术、摄 影、文学、电影以及哲学等领域。按照威廉- 米切尔的论述，“景观 不仅仅是一门艺术，而且是一种媒介……在此媒介中可以探寻到所有 文化的踪迹。”[81例如，19世纪中后期美国景观摄影师卡尔顿．沃特金 斯和蒂莫西. 奥沙利文将拍摄的风景照片进行对比, 引发了摄影作为 一种视觉媒介的本质讨论。前者的风景摄影具有隐喻和修辞性，它激 发着观众进入和开发这片土地的欲望，而后者的探险性摄影则极具反 邀请性，把观者拒之千里，阻止他们进入照片之中 ${ }^{[82]}$ 。通过两人的比较 论述，一方面我们探讨了美国西部的风景，另一方面又抛出了一个关 键议题: 摄影到底是具有一种审美想象力的艺术类型, 还是一种具有 客观记录性和科学性的媒介。

在罗莎琳. 克劳斯的另类论述中，她将1868年奥沙利文的风景摄 which co-exists and interacts with, as well as be independent of, the object. Secondly, landscape is not an entity consisting of a series of components, though according to Kant's agnosticism that a landscape does not exist on the whole - concrete landscape does exist, such as green spaces on street and paths in a park. Those ubiquitously landscapes are able to be endorsed for their own meanings by means of "landscape as it is in itself." [79]

According to the inner critique of new realism, one of the potential consequences is that landscape as a whole does not necessarily have a permanent reference and a meaning system, in the meanwhile, the existence and significance of landscape as a series of physical components could never be denied in a theoretical perspective. It might help interpretations of landscape avoid to fall into the thinking traps of both totalization and deconstructivism. Besides, new realism could hint some potentials of Landscape Architecture in the future: if Landscape Architecture peels off its representation and returns to itself per se, what could be expected from a further understanding on landscape experience? Perhaps, we could obtain some inspiring reflections referring to the object-oriented-ontology ${ }^{[80]}$, or explore further in the dimensions of autonomy and resistance of landscape.

Landscape criticism not only occurs in its own domain of knowledge, but also serves as an instrumental functionality on external systems, such as visual art, photography, literature, movie, and philosophy. In William John Mitchell's words, "landscape is not only an art but also a medium... in which all cultures could be found." ${ }^{\text {[81] }}$ Here, landscape acts as a prism to refract the thoughts and ideas in other related fields. For example, two types of photograph of natural landscapes, taken by American landscape photographers Carleton Watkins and Timothy O'Sullivan in the second half of the 19th century, were compared to address the ontological issue that photography in nature is a visual medium. In the photographs taken by Watkins, the landscape in western America is full of imagination, metaphor, and rhetoric, inviting people to gaze, to step in and to immerse in the scenery, or even exploit the land; those adventurous photographs taken by O'Sullivan show a strong exclusive sense that discourage the dialogue between viewers and the photos ${ }^{[82]}$. This comparative study not only offers us the knowledge of natural landscapes in western America, but also puts forward a key question: does photography refer to an art of aesthetic imagination, or a medium for truthfully and scientifically documenting?

Rosalind Krauss interpreted Sullivan's photos through an alternative way: she compared a landscape photograph taken in 1868 with a lithographic copy produced for a publication in 
影与其1875年的印刷版进行了比较性分析（图5，6）。她认为前者具 有一种神秘性，而后者则索然无味。克劳斯通过这一分析表明了这两 幅风景影像“属于不同的文化范畴……承载着截然不同的文化类 型……是两种相异的话语” [83]。克劳斯还分析了这两幅照片中景观的 差异性，其中一幅展示了有深度的景观，而另一幅则呈现出水平的、 压缩的空间状态，通过这种差异性，她探讨了绘画艺术的本质，即现 代主义绘画的本体论和合法性 ${ }^{[84 \mid 185]}$ 。

除了体现在摄影和绘画等视觉研究中之外，景观作为其他人文学 科的一种文化分析工具的应用亦司空见惯。例如，在西方左翼马克思 主义的批判理论视角之下，迪士尼主题公园是现代资本社会下的一种 奇观，其深层意义在于揭示奇观背后的意识形态、社会结构和文化模 式 ${ }^{[86]}$ 。再例如，在夏目漱石关于日本风景的描述之中，柄谷行人通过 其文本分析直接指向了日本之民族国家的现代性起源 ${ }^{[87]}$ 。

\section{5 景观批评的操作途径}

我们不仅应该知晓景观批评能够发生在哪些领域，或仅是理解景 观批评如何提升其对自身和对其他事物的认知，更重要的是，我们如 何实现景观批评 ${ }^{[83]}$ 。

一般来说, 景观批评被默认为是研究学者或作家的职责，而非 设计师的分内之事。实际上, 设计师群体与批评活动之间的关系远 比想象中要密切得多。在此，设计与批评不再是分离的，而是需以 相互结合的方式重新评估两者的关系。在展开论述之前，首先假设存 在着一种批判性景观 ${ }^{\circledR}$, 此类景观自然而然地具备了开放的批判性。

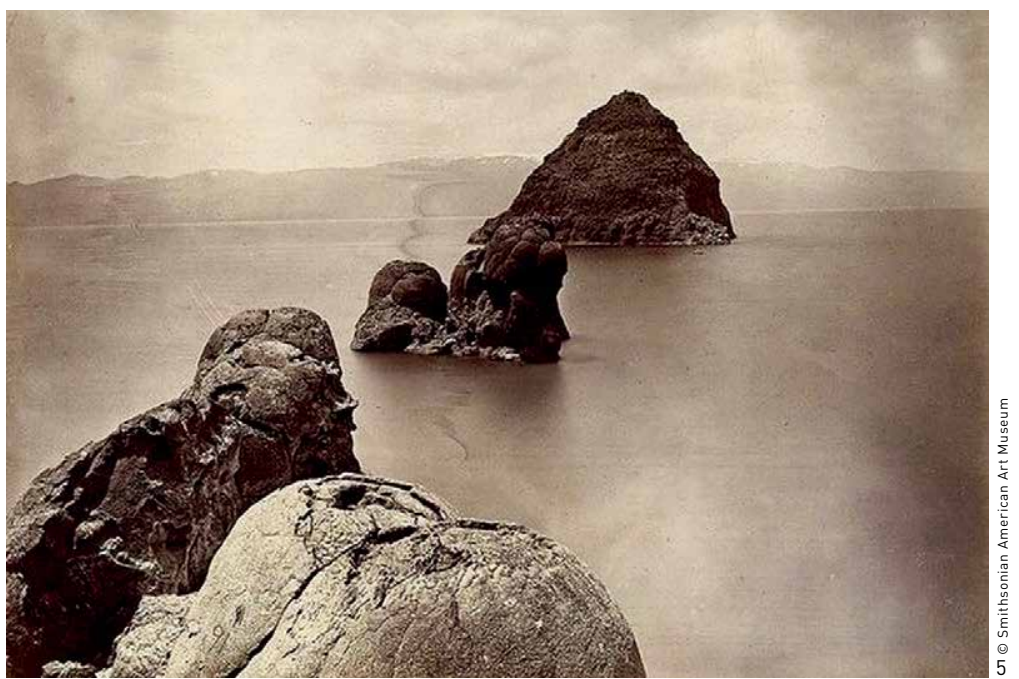

(11) “批判性景观”的概念 并没有被正式讨论过， 只有少数学者从自然的 只有少数学者从自然的 述, 见参考文献[89]。 domains of culture, they assume different expectations in the user of the image, they convey two distinct kinds of knowledge... as members of two different discourses." ${ }^{[83]}$ Krauss further pointed out that the same natural landscape was represented far differently that provide two spatial perceptions: one showed a landscape with layers in distance, and the other displayed a flat, horizontal, and compressed space. The difference hit the core agenda of painting art - the ontology and legitimacy of modernism painting ${ }^{[84[[85]}$.

It is commonly seen that landscape has been refered as a tool for cultural analysis in different disciplines of humanity. For example, through the lenses of radical Marxism, Disneyland is a dazzling grotesque of modern consumerism and capitalism, which mirrors the limp of social ideology, structure, and cultures ${ }^{[86]}$. Karatani Kojin reconsidered the origin of modernity in the nation through a re-examination on Soseki Natsume's words about Japan's natural landscape ${ }^{[87]}$.

\section{Landscape Criticism Operations}

Besides knowing what fields that landscape criticism could be applied in and how landscape criticism could help enhance people's awareness of landscape, it also requires us to learn the operations of landscape criticism ${ }^{[88]}$.

It is widely considered that landscape criticism is more like a job of critics and writers, rather than designers. But, in fact, designers and criticism are closely boned and intertwined; furthermore, design activity and critical activity would re-establish a mutualism relation to break down theoretical and practical obstructions. First of all, all the discussion is based on a hypothesis that acknowledges the substance of critical landscape ${ }^{\circledR}$. If the critical landscape still

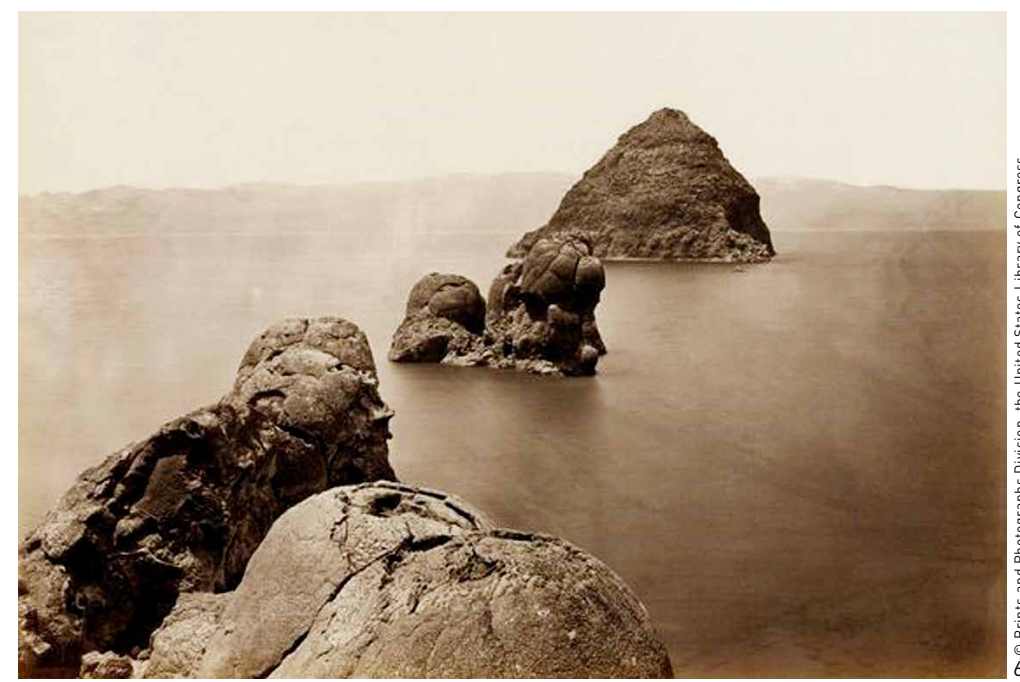

(1) To the author's knowledge, the concept of Critical Landscape has rarely been mentioned in academic research, except for few scholars' efforts from the perspective of pure nature. Source: Ref. [89].
5. 蒂莫西·奥沙利文于1867 年所拍摄的风景照片 经由平板印刷的奥沙利 文所拍摄的照片 (出版 时间: 1875年)

A landscape photograp taken by Timothy O'Sullivan, 1867.

6. Lithograph copy of O'Sullivan's photograph, 1875 
如果暂时不考虑批判性景观内在的批评价值，那么通过设计实践而产 生的景观批评则是另外一种可能的选择。设计一词来自于意大利语 “ disegno”，意为画在草稿纸上的线条或是图绘之前的某个概念性想 法 ${ }^{[00]}$ 。那么, 设计批评则应贯穿于景观的各个环节之中, 既包括建造之 前的概念构思、文本书写、交谈和图绘，也包含景观的营建和体验， 以及建成后的文字书写和视觉再现。故而，景观批评不再是评论家的 专属领域，景观设计师完全可以一也应该一一通过文本、图绘和建 造三种方式来质疑和挑战已经存在的景观天际线，以期实现景观批评 的操作可能性

在现代主义艺术中，语言总是处于被怀疑的位置，甚至被认为会 束缚思维。德国艺术史学家海因里希. 沃尔夫林就曾表示：“如果所 有建筑物都能够用文字表达出最深层次的含义, 那么它们就可以停留 在文字上了，既没有必要被建造，也没有必要被绘制 ${ }^{[91]}$ 。”这种观点 一方面暗示了景观批评包含的两种操作方式, 即图绘和空间营造, 另 一方面又隐晦地否定了书写之于批评的作用，即认为通过语言或写作 进行批评并不能说尽某事物。然而，在风景园林的批评史中，几乎所 有的批评都是书写完成的。例如，在现代主义景观设计中，其采取的 批评策略是直接反驳既定的思潮，将双方的论点置于如对称形式与空 间流动、装饰与功能这样的对立语境中，进而提出类似于宣言的新观 点。直到今天，这种写作传统仍未发生太大的变化。大部分的写作只 是在涉猎内容的广度上得到了显著的提高，只有极少数学者能够认识 到术语、行文逻辑和词语组合所传达的信息, 以及这三者具备的某种 内在的一致性 ${ }^{[92]}$ 。景观写作本身, 甚至写作的文体都充当了一种实现批 评的具体操作形式。

与文字系统一样, 视觉图像系统也是景观再现的重要媒介。一方 面, 景观设计师获取独立职业地位所依靠的主要途径之一就是自觉地 运用视觉图像 ; 另一方面，图像的生产和制造也悄然地影响了风景园 林学科的发展。值得我们重视的一个现状是，在当今中国风景园林的 领域内，图像操作的直接对象是建造，而非概念的思辨，这就导致了 压制了图绘创造力的潜力和可能性 ${ }^{[93]}$ 。景观的图像 (这里特指图绘) 不仅只是某种设计的表达方式或是用于被动地呈现某些概念和建造方 式, 它还能够充当一种激发思维的媒介, 凭借其自身的创造力主动地 介入到景观设计中 ${ }^{[04[05]}$ 。而从强调智识创造的角度来讲，景观设计师詹 姆斯· 科纳一直倡导图像等再现技术所蕴藏的创造力, 并且进一步认 为, 再现技术将成为促进未来景观设计创新的重要推动力 ${ }^{[96[197]}$ 。 remains under-examined, the design activity possibly offers an alternative way to operate landscape criticism, regardless of its theoretical construction. Etymologically, the word Design comes from the term Disegno in Italian, meaning drawing lines on a sketch or the conceptual ideas before drawing ${ }^{[90]}$. In this sense, criticism on design could range from conceptual design, text writing, conversation, drawings, physical space-making and experience to literary and visual documents on built projects. Landscape criticism would not be taken granted for the job of critics, landscape architects could, and should, operate criticism in forms of writing, drawing / image, or physical construction to explore the possibilities for promoting critical thinking on landscape designs.

Language is often questioned and rejected in modernism arts as an enemy of imagination. German art historian Heinrich Wolfflin argued that "if it were possible to express in words the deepest content... all buildings... could have remained unbuilt, unfashioned, or unpainted. ${ }^{\left[{ }^{[91]}\right.}$ Such viewpoint, on one hand, admits that there are two operational types of landscape criticism, while implying that writing, as one of the two, fails to represent a criticism thoroughly, on the other hand. However, almost all of the criticism on Landscape Architecture were completed by writings in the past. For example, in modernism landscape design, most criticisms challenging the predominant discourses put forward controversies, such as symmetrical form with spatial mobility, and decoration with function, whose writing style and strategy still have a great influence on contemporary design criticisms. Although the territory of critical writing has been largely expended, only few scholars could be aware of the internal coherence between terms, writing logic, and phraseology ${ }^{[92]}$. That is to say that writings on landscape, including the texts themselves, could serve as an operational instrumentality for criticism on landscape design.

As important as writing, visual image is also a medium of landscape representation. Similar to architecture, visual image is key to the profession of landscape design, and related graphic drawing and producing has significantly influenced on the development of Landscape Architecture. However, in the field of Landscape Architecture in China, graphic drawing is only applied in responding to the issues in physical construction, rather than critical thinking on concepts, shackling the creativity and potential of landscape drawing ${ }^{[33]}$. Visual image, drawing here it is, could be simply understood as a tool to express design ideas, concepts, or construction details; it also acts as a creative agency to inspire and improve landscape design ${ }^{[94][95]}$. For landscape architect James Corner, the creativity of landscape drawing would drive the future development of landscape design through 
在具体的图绘表现中, 景观设计师劳瑞. 欧林的作品显露出特定 的批评内涵。如图7所示, 近距离的罂粟花和远距离的小麦地被并置在 一个画框之中, 欧林把视觉和触觉上的悖论呈现在一个界面上, 暗示了 触觉感受与视觉感知之间的体验差别。欧林试图采用双重焦点的图像， 赋予人们一种场地纵深感的不同体验。如果先看罂粟花 (近景) , 再看 麦田（远景），会进一步加强远距离的视觉体验与近距离的触觉体验之 间的辩证关系 ${ }^{[98]}$, 即近距离的身体触觉使得视觉失效了, 而远距离的凝 视能够使触觉不再具有感知力, 此时, 移动的身体随着距离的变化与对 象发生了特定的体验关系。换句话说，欧林试图用一种文学和现象学的 方式来观察和描绘远与近。

当然, 景观的视觉图像系统不仅仅包含图绘的形式, 还涉及图解 和地图术等其他类型 ${ }^{[99]}$ 。以地图术为例：通过创造场域、数据提取和建 立关系三种操作方式, 地图术实现了对场地进行有针对性的筹划, 以期 发现和挖掘各种场地的可能性。地图术实践的创新性不在于形式, 而在 于将已有的场地信息中进行具有创造性和重组性的探索 ${ }^{[100]}$ 。在此意义 上，景观图像的本质属性就隐含着各种潜在的批判力。在此，如何释 放具有创造性的、敏锐的、分析的力量，应成为景观设计师首要的关 注点之一。
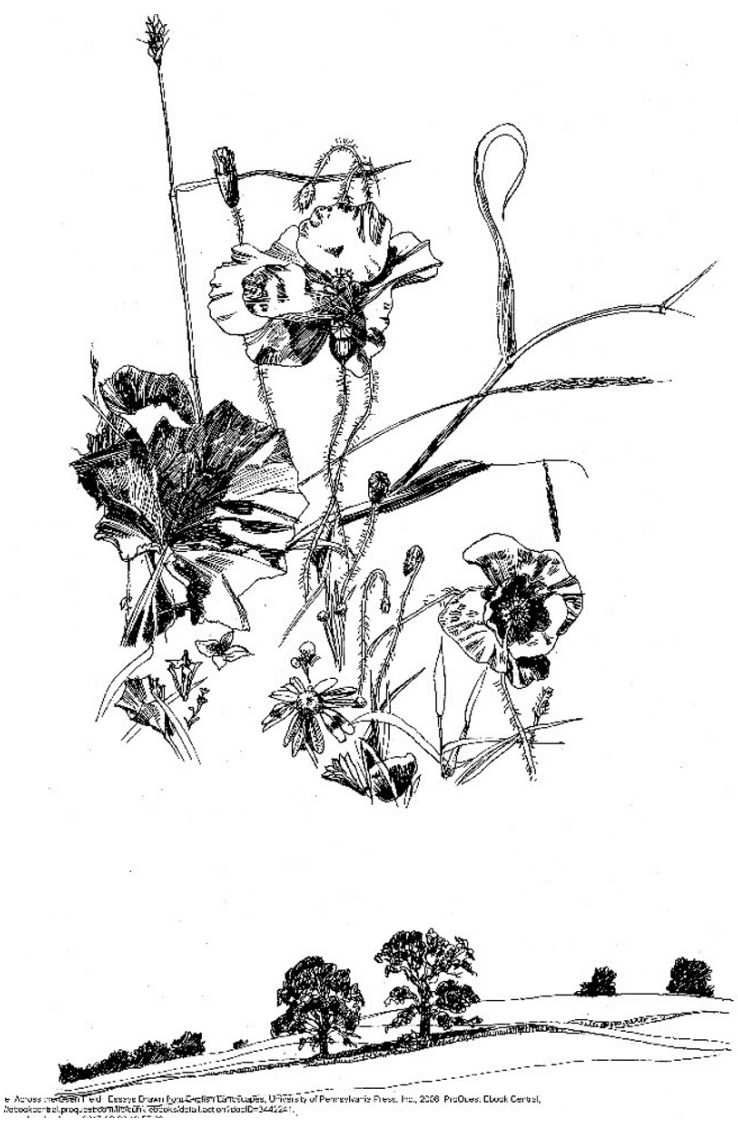

representational techniques and cultural imagination ${ }^{[96[97]}$.

The graphic sketches drawn by landscape architect Laurie Olin often reflect his consideration on landscape criticism. As shown in Figure 7, poppies in the foreground and a wheat field in the background are juxtaposed, which describes the inconsistency in visual and haptic senses. Olin employed a double-focus layout to engender the spatial layers in distance. If we look at the poppies first, then move to the wheat field, the sense would be further strengthened ${ }^{[98]}$, and the dialectical relationship between visual and haptic sensation would be intensified. The viewers' experience would constantly change in the switch of watching objects. Olin used a literary and phenomenological approach to observe and portray the landscapes at hand and in distance.

Image includes drawings, diagrams, and maps ${ }^{[99]}$. Mapping, for example, as a means of planning, presents the possibilities of a site through site locating, data screening, and relation building. Prior to landscape formation, mapping is also a process of exploration, discovery, and enablement of possibilities ${ }^{[100]}$. In this sense, landscape image has a potential to stimulate criticism. Landscape architects need to explore and make the best of the potentials of creativity concealed in the visual images.

If we put the creativity of image on design aside and focus on the critical speculations on landscape, then the drawing Landscript (Fig. 8), created by artist Bing Xu, as well as the exhibition (Fig. 9) by Joseph Kosuth, could be reviewed as cases re-examining the relationship between landscape and media in terms of representation and inspiring people's critical thinking on the relationships between text, image, and landscape ${ }^{[101]}$. Richard Weller produced a series of photomontages (Fig. 10) that also show his critical thinking on the essence of landscape, suggesting a controversy that what is the intrinsic quality of landscape? Is it the surreal, metaphoric, or poetic imagination (the figure of Dali in the left bottom) or the scientific or honest knowledge (the geological map in the top left)? Furthermore, the slogan at the bottom of the image - "this is not a landscape," in a style of René Magritte - triggers the seeking for the answer of what the reality of a landscape is in terms of representation. Reflections on the authenticity of landscape exists in words, images, and physical space, separately or together. This photomontage allows for conceptual speculations and provides operative possibilities for landscape criticism ${ }^{[102]}$.

Besides writing and visual image, landscape criticism could also be represented in a way of space-making, though built landscapes, to a great extent, could not equip with critical meaning without challenging concepts or creative drawings. In his early work The Manhattan Transcripts, Bernard Tschumi employed a series of images of montage to express his architectural ideas 

2008年)。

8. 徐冰绘制的《风景写生》 (绘制时间: 2001年)

约瑟夫.科苏斯的展览 《一把与三把椅子》 (展出时间: 1965年) 创作媒介为木折椅、 装䄜的椅子照片, 以及 “椅子” 于字典中的定 义的放大装褤照片。

10. 理查德.韦勒与汤姆. 格 里菲斯合制的蒙太奇照 片（创作时间：2001 年)。图片来源: 参考 文献[111]。

7. Timeless and Tranquil (2008), by Laurie Olin.

Landscript (2001), by

Bing Xu.

One and Three Chairs (1965), by Joseph Kosuth. Mounted photograph of a chair, and mounted photographic enlargement of the dictionary definition of "chair.

10. Photomontage (2001), by Richard Weller and Tom Griffiths. Source: Ref. [111].
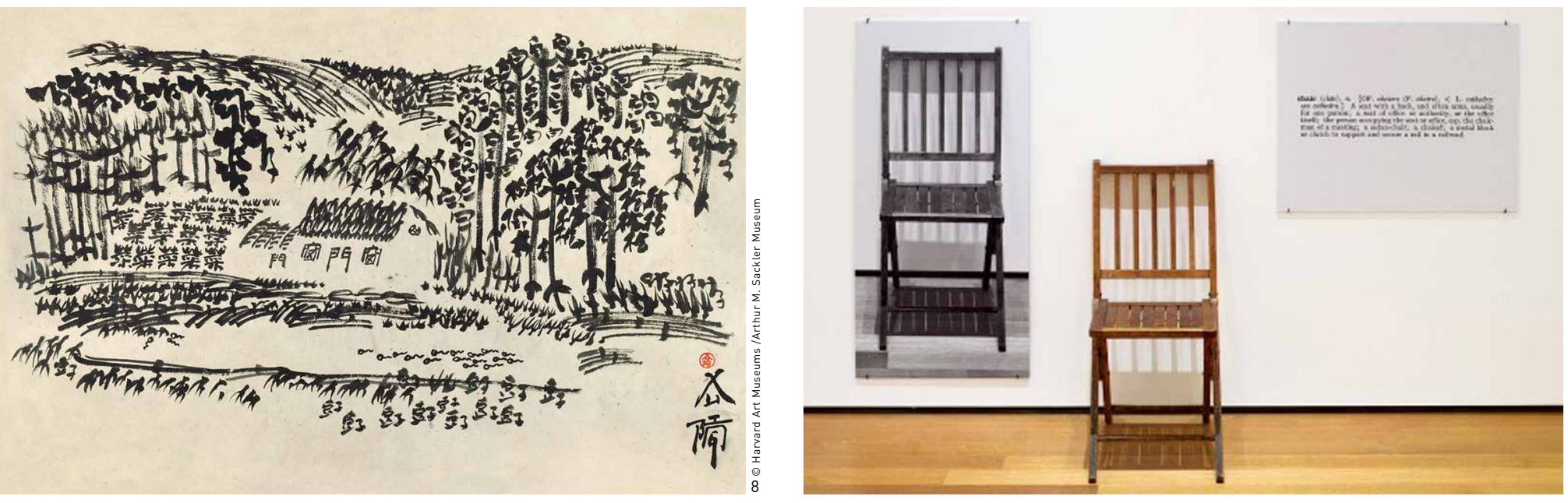

如果我们暂时跳出图像之于设计的创造性作用，以批判性的视 角切入到景观的阐释之中，那么，艺术家徐冰的作品《风景写生》

(图8) 与约瑟夫·科苏斯的展览 (图9) 都批判性地思考了景观于 不同再现媒介的关系，再一次激发起人们对于景观的文字、图像和现 实之间关系的思考 ${ }^{[101]}$ 。与之类似，理查德. 维勒制作了一系列的图 像蒙太奇作品（图10），它们也具备批判性思考景观涵义的潜力：到 底是超现实主义的想象力能够揭示景观的真实性（图中左下角的达利 形象)，还是理性科学主义的精确度能够展示景观的本质（图中左上 角的地理测绘图) ? 此外，图片下方的玛格利特式的标语“这不是景 观”进一步强化了“到底是什么构成了风景”的追问：是临摹线描的 相似性, 是文字的所指与能指, 还是触手可及的客体存在? 抑或三者 之间的复杂关系本身才是真实的风景 ? 此类图像悬置了诸多景观概念 的思辨，亦可被视为景观批评的具体操作 ${ }^{[102]}$ 。

除了景观书写和视觉图像之外, 景观批评的操作还能够通过具体 空间的营造来实现；但在很大程度上，建成景观所具有的批判力依然 需要凭借其概念本身所具有的颠覆性及其图像系统的创造性来实现。 在伯纳德. 屈米早期的著作《曼哈顿手稿》中，他通过各种图像的蒙 太奇组合表达了空间流动性和偶发性事件。而在拉维莱特公园中，屈 米对应地将一条公园路命名为“电影大道”，继续探讨了视觉图像的 拼贴与真实体验之间的潜在关系。屈米的建筑理论既没有沿着抽象的 形式自主性的路径，也不是后现代主义符号式的历史感伤，而是另辟 踇径地提倡一种具有计划性、行动性和事件性的建筑观念 ${ }^{[103]}$ 。现代主 义假设某个特定的空间只能够容纳特定的事件发生, 但屈米却打破了 这种空间与事件之间一一对应的稳定关系。例如，假如一座教堂可以 被用作打保龄球的话，那么教堂的原有功能就与新的功能并置到了一 起。以此为逻辑基础，拉维莱特公园通过点、线、面三种空间的相互 叠加，形成了一个反常的、复杂的、异质的空间。在这个空间中，原 来各自的空间计划和事件被重新组织。这一方面使得该公园保持一种 动态的、开放的、不确定的、不可预期的空间属性，另一方面还能满 related to programmatic organization of space, event, and mobility. In La Villette Park, Tschumi continued to explore the relationship between image sequential and real experience during movement by naming a parkway "Movie Strip" where visitors could experience a montage of sequences and frames of landscape. Instead of advocating abstract formal autonomy or historical sentiments of post-modernism, Tschumi attempted to employ a new architectural philosophy with programs, activities, and events ${ }^{[103]}$. For example, it is widely assumed in modernism that one specific architectural space can only be used for one simple purpose; Tschumi's design challenged this correlation, making space and places with mixed functions - if a church could also accommodate activities like playing bowling, then the church becomes a mixed-program place - in so, various layers of nodes, strips, and zones were superimposed and organized in the park,

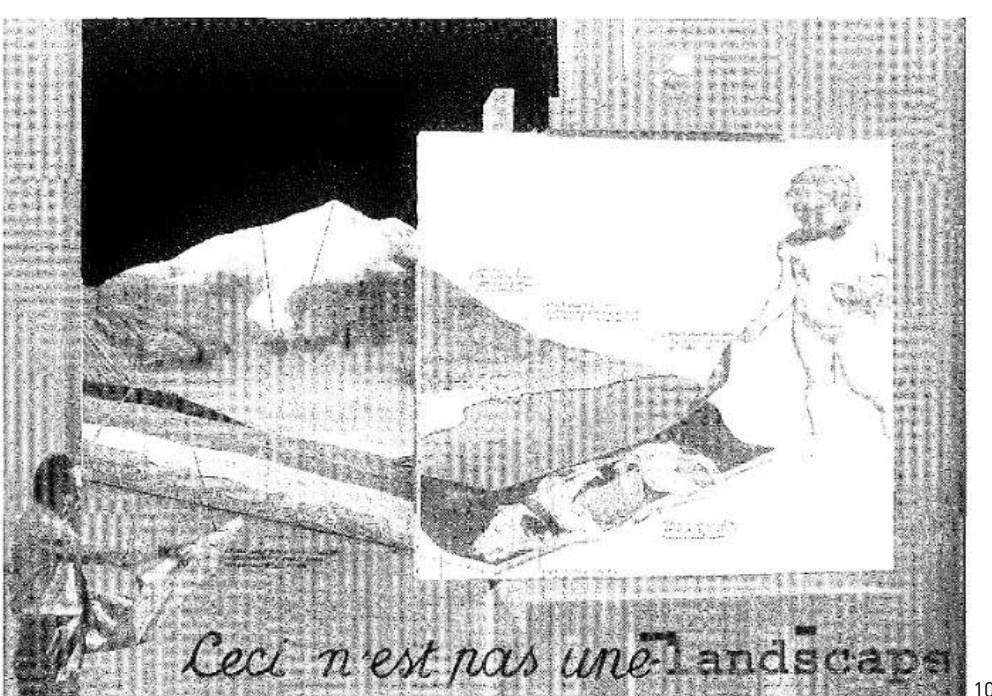


足人们日常生活体验的各种基本诉求 ${ }^{[104]}$ 。在此案例中, 我们发现著书 立言、操作视觉媒介以及空间营建共同构成了景观批评的一体多面, 它 们之间不决然独立, 也不完全如影随行。拉维莱特公园的概念、图绘和 建造过程前后历经20余年, 其艰涩的概念构思、巧妙的图像技术, 以及 务实的建造以一种既连贯又断裂的方式, 全面而集中地描绘了景观批评 的基本操作轮廓。

\section{6 结语}

景观批评是一种穿梭于现实和过往之间的历史性的理论构建活 动, 它既包括具体空间的建造和设计, 也包括积累性的风景空间, 以及 再现媒介中的风景。本文依照章节分别论述了5 部分的内容, 其论述内 容和组成结构一方面间接地强调了景观历史、理论、批评与设计实践的 相互关系, 另一方面又直接地阐释了景观批评可能包含的各种维度。

严肃的景观批评从来都不是依靠单向思维完成的,一方面其过程 要求严谨的逻辑推理, 正如批评家抽丝剥茧地分析景观材料、构图结 构、形式、空间、功能、氛围、感知、城市形象、社会效应以及文化品 质等, 尽其所能地抽离和提取每个符号背后的历史信息, 层层推演, 最 终建构出符合逻辑的观点; 另一方面, 从感性角度出发, 批评家只有在 长时间地与对象接触之后, 才能将其进行理性的表达。洞见性的观点不 可能脱离视觉上的感性积累而自动获取, 只有在情感上真正击中了批评 家的内心, 高质量的景观批评才可能产生。有的学者认为理论的理性先 于直觉的感性, 另一些学者则相信后者先于前者, 本文则强调两者自身 远远不是追求的终极目的, 它们之间的互动关系既是起点, 也是过程。 恰在此互动关系中，另类的批评才有可能迸发出来 ${ }^{[105]}$ 。

无论景观批评如何摇摆于感性与理性、随意与严谨之间, 可以确 定的一点是, 景观批评是一种多向思维交织的智力活动。景观批评正如 穿越迷宫一般, 时而使人气馁, 时而令人充满希望。批评家在复杂矛盾 的心理状态之下, 凭借着记忆不断地身体力行, 以期走出那个看似永远 没有尽头的迷宫。或许更大的讽刺在于, 那根本不是一个迷宫, 而是一 个没有确定出口的花园, 探求者似乎永远被困于这无边无尽的网络之 中。但问题的关键在于, 这些难道能够成为我们放弃探索景观批评的理 由吗 ${ }^{[106]}$ ?

维护和发展景观批评的动力, 以及克服景观批评的困境, 并非仅 仅来自于此项活动的操作层面, 更源于批评家内心的责任感, 一种激发 which created an alternative, sophisticated, and hybrid landscape with mixed functions and allowed for dynamic possibilities of spatial uses and experiences ${ }^{[104]}$. This case demonstrated that how the three operation ways of landscape criticism - writing, visual image, and physical construction - play their roles, intensively or comprehensively, in the conceptual design, representative techniques, and construction of La Villette Park.

\section{Conclusions}

Landscape criticism is sort of historically theoretical activity constructed by means of the shuttle of past and present, which focuses on topics of concrete design, landscape heritages and represented landscapes. This paper discusses five main contents, which have implicitly emphasized the relationship among landscape history, theory, design and criticism on the one hand, and also explained explicitly various dimensions of landscape criticism.

Serious landscape criticism could never be completed in a single mode of thinking. On one hand, logical reasoning is required when examining and processing the landscape materials, components, structure, forms, space, functions, atmosphere, perception, image, social recognition, and cultural preference. Critics painstakingly extract valuable facts concealed in the superficial mass step by step to form some reasonable viewpoints. On the other hand, landscape criticism is also a kind of selfless activity that means critics cannot express insightful views without immersing themselves into the landscape materials and obtaining sensational and emotional experience. Meanwhile, those unspeakable shocking moments could stir particular insights and convincing viewpoints in the state of sensibility. As scholars often debate on the priority between rationality and sensibility, this paper proposes that the interactive relationship between these two can be seen as both the starting point, and the process of landscape criticism ${ }^{[105]}$.

No matter how sensibility or rationality could influence on landscape criticism, one thing is for sure that is an intellectual activity with multi-dimension thinking. To Compose one piece of criticism, sometimes critics usually feel confusing and frustrated in the process, and sometimes inspired and promising, just like running through a maze. The mixed feeling drives critics to refresh memories, to imagine, and to criticize. Ironically, it is highly likely that it is a maze without any exits, and critics might be lost in the dizziness. But, this depressing dilemma cannot be an excuse that we give up the exploration in landscape criticism ${ }^{[106]}$.

To overcome the plight and to promote the development of landscape criticism cannot simply reply on the operation activities; critics' inner responsibility and the sense of mission 
和唤醒公众对于各种蕴藏于风景中的感性情感的使命感。随着社会结 构和文化形态的改变, 大众思考、辨识和欣赏景观的能力几乎完全丧 失了。如何打破“景观就是绿化”的认识局限，如何重塑公众对于景 观的批判性认知便是关键所在，也是批评家的应有职责。如果将景观 泛化为世界, 那么针对景观的批评就是对于世界的批评，这种等价逻 辑的危险性在于让景观批评陷入到所有的话语之中。此时，批评家就 需要在包罗万象与具体而微之间保持某种平衡，同时注意言说的可能 性，使批评不落入空洞无物、无病呻吟。

一方面, 批评需要与作品以及设计师保持一定的距离, 批评的产 生基于尊重而非屈从，批评家需要一种极其敏锐的判断力，直指时 代症结, 给予当代乱象一个相对稳定和清晰的人文价值判断。在吉 奥乔. 阿甘本的语境中，批评家充当了“当代人”的身份，他们既不 依附于时代, 又与之保持密切的联系。另一方面, 假如对景观批评抱 有一种批判性思维, 那么我们仍无法确定的是 : 批评到底是主动的还 是被动的，或者说，批评是否是一种体制化的话语? 它是否时刻控制 着我们的思维? 这是否要求我们针对任何事物都需标新立异、语出惊 人? 毫无节制地、盲目地追求表面上的批评比无所作为更加不可取, 为了批评而批评与为了作品而批评之间的界限充当了引发批评自身危 机的國值 ${ }^{[107]}$ 。真正重要的并非批评活动本身, 而是批评活动可能产生 的效应, 批评活动旨在让大家认识到, 景观的潜能在于它让人发现、

体悟和遇见, 最后将景观这个间接的外在蜕变为直接的内在, 使我们 与景观亲密无间。批评在很大程度上只是一种姿态, 而非建设性行 为。正如本文批判性地讨论景观批评的可能性，不是为了凭空地、刻 意地制造和倡导批评, 而是从景观本身出发, 对批评的必要性进行辩 护。这个举动本身就是一种关于风景园林学领域的批评，换言之，景 观批评即风景。LAF

致谢

本文的第二部分发表于2014年中国风景园林年会, 获得了论文二等奖。本文经过了新一轮的重新修改和扩 充。特别感谢清华大学建筑学院杨锐教授在本文写作期间给予的指导、帮助和鼓励。感谢两位匿名评审者 对本文的宝贵意见, 以及曹越博士和许愿博士亦给予本文诸多建议。最后感谢《景观设计学》期刊编辑部 对于本文英文翻译及校对的贡献。

注释

作者研究方向: 陈从周与中国园林, 景观历史、理论与批评。 to rouse people's emotions about landscape and their interests to appreciate landscapes are also vital to the promotion of landscape criticism. The dramatic changes in social structure and cultural patterns have caused a huge limp in terms of how people understand, recognize, and appreciate landscape. For critics, it is also important to help people rebuild their understanding on landscape - one of the public misconceptions is that landscape is a profession of planting trees. Meanwhile, we need to be clear that if we consider the discourse of landscape criticism could be expended to all the areas of philosophy concept and physical reality on the world, then landscape criticism would lose its significance. So critics need to take their targeting territory carefully and seriously, avoiding in vain or fuss.

On one hand, criticism has to be detached from the original contexture of the design, and critical thinking and perspicacity is necessary for critics to examine historical, social, and cultural values in the aberrant world. Critics, in Giorgio Agamben's words, act their role of Contemporary, keeping a distance with their own times yet basing upon it. On the other hand, if we step back and ponder the activity of landscape criticism with critical thinking, we would find that we still confuse about whether criticism is an institutionalized discourse or not? Has it reshaped our minds? Do we need to be unorthodox all the time?... In fact, immoderate, blind attacks are not criticism. The threshold of triggering its own crisis of landscape criticism emphasizes more on the activity itself rather than effect ${ }^{[107]}$. Landscape criticism aims at educating and encouraging people to discover, experience, and comprehend the potentials of landscape, and to take landscape as a part of our life. In this sense, criticism offers a greater significance as a gesture or a tool, instead of a constructive activity, in Landscape Architecture. In this paper, the discussion on the possibilities of landscape drives at defending the necessity of landscape criticism, through which criticism becomes a creative agent. Saying, landscape criticism is also a landscape. LAF

\section{ACKNOWLEDGMENTS}

The second part of this paper was published in the Annual Conference of Chinese Society of Landscape Architecture in 2014, winning a second-grade prize in Paper Competition. This paper is a completely Architecture in 2014, winning a second-grade prize in Paper Competition. This paper is a completely
rewritten version. The author would like to thank Prof. Rui Yang from Tsinghua University for his generous rewritten version. The author would like to thank Prof. Rui Yang from Tsinghua University for his generous
help and encouragement for this paper. My gratitude also extends to two anonymous reviewers, as well as Dr. Yue Cao and Dr. Yuan Xu for their previous suggestions on this paper. Finally, I would like to thank the editorial team at Landscape Architecture Frontiers journal for their efforts on the translation and proofreading of this paper.

\section{NOTE}

The author's research interest: study on Prof. Congzhou Chen and Chinese Gardens, and history, theory and criticism of landscape. 
[1] Tafuri, M. (1980). Theories and History of Architecture IG. Verrecchia, Tran.). London: Granada Publishing.

2] Debray, R. (2014). Life and Death of the Image: History of the Western View of Landscape (X. Y. Huang \& J. H. Huang Trans.) (p. 176). Shanghai: East China Normal University Press.

[3] Hall, D. L., \& Ames, R. T. (1987). Thinking through Confucius (pp. 11-25). New York: State University of New York Press.

[4] Yu, Y. S. (2014). Boundary between Heaven and Man: The Origin Exploration of Chinese Ancient Ideologies. Beijing: Zhonghua Book Company.

[5] Jin, G. T. \& Liu, Q. F. (2015). Ten Lectures on Chinese Ideological History (pp. 15-18). Beijing: Law Press.

[6] Berque, A. (1993). Beyond the Modern Landscape. AA Files, (25), 33-37.

7] Jullien, F. (2017). Vivre de Paysage ou Limpensé de la Raison (L. Zhuo, Tran.) (pp. 14-17). Shanghai: East China Normal University Press.

[8] Monk, R. (1990). Ludwig Wittgenstein: The Duty of Genius. New York: Free Press

[9] Yu, K. J. (1987). Development of Landscape Concept and Study. Journal of Beijing Forestry University, 9(4), 433-439.

[10] Yang. R. (2010). Meanings of "Feng Jing." Chinese Landscape Architecture, (9), 1-3.

[11] Olwig, K. R. (1996). Recovering the Substantive Nature of Landscape. Annals of the Association of American Geographers, 86(4), 630-653

[12] Office of the Degree Committee of the State Council. (2011). Demonstration Report on Adding Landscape Architecture as the First Level Discipline Chinese Landscape Architecture, (5). 4-8.

[13] Daskalakis, G., Waldheim, C., \& Young, J. (Eds.) (2001). Stalking Detroit. Barcelona: Actar.

[14] Mostafavi, M., \& Najle, C. (Eds.) (2003). Landscape Urbanism A Manual for the Machinic Landscape. London: Architectural Association.

[15] Truniger, F. (Ed.) (2013). Introduction: From the Aesthetic to Dynamic Landscape. Filmic Mapping: Documentary Film and the Visual Culture of Landscape Architecture (pp. 13-25). Berlin: Jovis Verlag GmbH.

[16] Waldheim, C. (Ed.) (2006). The Landscape Urbanism Reader (pp. 35-67). New York: Princeton Architectural Press.

[17] Mu, X. D. (2015). Critical Landscape: Truth and Vanity of Landscape Urbanism (Master's Thesis). Available from CNK database

[18] Jussim, E., \& Lindquist-Cock, E. (1985). Landscape as Photograph (p. 59). New Haven: Yale University Press.

[19] Virilio, P. (2000). A Landscape of Events (J. Rose, Tran.).
Cambridge: The MIT Press.

[20] Stilgoe, J. R. (2015). What Is Landscape? Cambridge: The MIT

[21] DeLue, R. Z., \& Elkins, J. (Eds.) (2008). Landscape Theory. New York: Routledge.

[22] Yeh, M. (1991). Modern Chinese Poetry: Theory and Practic since 1917 (p.188). New Haven: Yale University Press.

[23] Berque, A. (2013). Thinking Through Landscape. New York: Routledge.

[24] Jameson, F. (1985). Architecture and the Critique of Ideology. In J. Ockman (Ed.), Architecture, Criticism, Ideology (pp. 51 52). Princeton: Princeton Architectural Press.

[25] Marion, J. (2004). The Crossing of the Visible (J. Smith, Tran.). California: Stanford University Press.

[26] Benjamin, W., \& Arendt, H. (1992). Illuminations (Z. Harry, Tran.I. London: Fontana Press.

[27] Eliot, T. S. (1975). The Function of Criticism. In F. Kermode (Ed.), Selected Prose of T. S. Eliot (p. 75). New York: Harves Books.

[28] Podro, M. (1982). The Critical Historians of Art. New Haven Yale University Press.

[29] Tafuri M. [1987]. The Sphere and the Labyrinth, Avant-Gardes and Architecture from Piranesi to the 1970's (P. d'Acierno \& R. Connolly, Trans.J. Cambridge: The MIT Press.

[30] Calinescu, M. (1987). Five Faces of Modernity: Modernism, Avant-garde, Decadence, Kitsch, Postmodernism. Durham Duke University Press.

[31] Venturi, R. (1966). Complexity and Contradiction in Architecture. New York: Museum of Modern Art.

32] Lyotard, J. F. (1984). The Postmodern Condition: A Report on Knowledge (G. Bennington \& B. Massumi, Trans.). Manchester: Manchester University Press.

[33] Weller, R. (2006). An Art of Instrumentality: Thinking through Landscape Urbanism. In C. Waldheim (Ed.J, The Landscape Urbanism Reader (pp. 67-85). New York: Princeton Architectural Press.

[34] Chen, C. Z. (1984). On Chinese Gardens. Shanghai: Tongi University Press.

[35] Bao, S. X. (1984). Poet's Emotion, Scholar's Philosophy - A Conversation with Professor Chen. Urban Planning, (2), 2223,13 .

[36] Yu, K. J. (1998). Challenges and Chances of Chinese Landscape Architecture from the View of Three Phases of Landscape Architecture Development in the World. Chinese Landscape Architecture, (1), 17-21.

37] Eisenman, P. (2014). Aspects of Modernism: Maison Domino and the Self-Referential Sign. Log, (30), 139-151.

[38] Venturi, L. (1964). History of Art Criticism (C. Marriott, Trans.)
New York: E. P. Dutton.

39] Wellek, R., \& Warren, A. (1949). Theory of literature (pp. 2937). New York: Harcourt Brace and Company.

[40] Hunt, J. D. (1992). Garden History: Issues, Approaches, Methods. Washington D. C: Dumbarton Oaks Research Library and Collection.

[41] Conan, M. (Ed.) (1999). Perspectives on Garden Histories Washington D. C: Dumbarton Oaks Research Library an Collection

[42] Tournikiotis, P. (2001). The Historiography of Modern Architecture. Cambridge: The MIT Press.

[43] Treib, M. (Ed.) [1993). Modern Landscape Architecture: A Critical Review. Cambridge: The MIT Press.

[44] Walker, P., \& Simo, M. (1996). Invisible Gardens: The Search for Modernism in the American Landscape. Cambridge: Th MIT Press.

[45] Doherty, G., \& Waldheim, C. (Eds.) (2016). Is Landscape...? Essays on the Identity of Landscape. New York: Routledge.

[46] Wolschke-Bulhman, J. (1996). Twenty-Five Years of Studies in Landscape Architecture at Dumbarton Oaks (p. 78). Washington D. C.: Dumbarton Oaks Research Library and Collection.

[47] Song. B. M. (2007). Description, Explanation, Judgment The Research on Modern Landscape Architecture Criticism Method. Urban Environment Design, (5), 106-108.

[48] Li, J. Q. (2008). Establishing the Contemporary Landscape Architecture Criticism. Chinese Landscape Architecture, (10), 1-7.

[49] Andersen, N. M. (2012). Writing Landscape: Criticism Now. Journal of Landscape Architecture, 7(2), 91.

[50] Swaffield, S. R. (2006). Theory and Critique in Landscape Architecture: Making Connections. Journal of Landscape Architecture, 1(11) 22-29.

[51] Riley, R. B. (2015). On Criticism, the Camaro in the Pasture: Speculations on the Cultural Landscape of America (p. 90). Virginia: University of Virginia Press.

[52] Owen, S. (1992). Readings in Chinese Literary Thought (p. 28). Cambridge: Harvard University Press.

[53] Kant, I. (2007). Critique of Pure Reason (N. K. Smith, Tran.). New York, Palgrave Macmillan.

[54] Foucault. M., \& Gros, G. (Ed.) (2011). What Is Critical, in The Government of Self and Others: Lectures at the College de France 1982-1983. New York: Palgrave Macmillan.

[55] Abrams, M. H. (1953). The mirror and the lamp: romantic theory and the critical tradition. Oxford: Oxford University Press.

[56] Benjamin, W. (1986). Theses on the Philosophy of History (H. Zohn, Tran.). In H. Arendt (Ed.), Illuminations (pp. 257-258). 
New York: Schocken Books

[57] Danto, A. C. (1981). The Transfiguration of the Commonplace: A Philosophy of Art. Cambridge: Harvard University Press.

[58] Rowe, C. (1982). The Mathematics of the Ideal Villa and Other Essays (pp. 2-27). Cambridge: The MIT Press.

[59] Bell, C. (1914). The Aesthetic Hypothesis. In F. Frascina \& C. Harrison (Eds.J, Modern art and Modernism: A Critical Anthology. New York: Harper \& Row.

[60] Fried, M. (1998). Art and Objecthood: Essays and Reviews. Chicago: University of Chicago Press.

[61] Jackson, J. B., \& Horowitz, H. L. (Ed.) (1997). Landscape in Sight: Looking at America (pp. 227-228). New Haven: Yale University Press.

[62] Bachelard, G. (2014). The Poetics of Space [M. Jolas, Tran.]. New York: Penguin Group.

[63] Dong, Y. G. (2013). Rockery in Suzhou Museum. Landscape Architecture, (2), 156-157.

[64] Zizekm, S. (2006). The Parallax View. Cambridge: The MI Press.

[65] Heidegger, M. (2008). The Original of the Work of Art. In D. F. Krell (Ed.), Martin Heidegger: The Basic Writings. New York Harper Perennial Modern Classics.

[66] Barthes, R. (1982). Writers, Intellectuals, Teachers. In S. Sontag (Ed.J), A Roland Barthes Reader (p. 379). New York: Hill and Wang.

[67] Dirks, N. B. (1990). History as a Sign of the Modern. Public Culture, 2(2), 25-32.

[68] Merleau-Ponty, M. (1958). Phenomenology of Perception IC. Smith, Tran.J. London: Routledge.

[69] Cosgrove, D., \& Daniels, S. (Eds.) (1989). The Iconography of Landscape: Essays on the Symbolic Representation, Design and Use of Past Environments. Cambridge: Cambridge University Press.

[70] Corboz, A. (1983). The Land as Palimpsest. Diogenes, 31(121) 12-34.

[71] Cosgrove, D. E. (1984). Social Formation and Symbolic Landscape (pp. 13-15). Madison: University of Wisconsin Press.

[72] Cosgrove, D. E. (1986). Introduction to Social Formation and Symbolic Landscape. In R. Z. Delue, \& J. Elkins (Eds.) Landscape Theory. New York: Routledge.

[73] Berman, M. (1983). All that Is Solid Melts into Air: The Experience of Modernity. New York: Verso.

74] Jackson, J. B. (1953). The Westward-Moving Hous Landscape, 2(3), 8-21.

[75] Wilson, C., \& Groth, P. (Eds.) (2003). Everyday America: Cultural Landscape Studies after J. B. Jackson (p. 15). Berkeley: University of California Press.
[76] Meinig, D. W. (Ed.) (1979). The Interpretation of Ordinary Landscapes: Geographical Essays. Oxford: Oxford University Press.

[77] Olin, L. (1988). Form, Meaning, and Expression in Landscape Architecture. Landscape Journal, 7(2), 149-168.

[78] Hunt, J. D. (2000). Greater Perfections: The Practice of Garden Theory. Philadelphia: University of Pennsylvania Press.

[79] Gabriel, M. (2015). Why the World does not Exist (pp. 1-15) Massachusetts: Polity Press.

[80] Bryant, L., Srnicek, N., \& Harman, G. (Eds.) (2011). The Speculative Turn: Continental Materialism and Realism. Melbourne: Re. Press

[81] Mitchell, W. J. T. (1994). Imperial Landscape. In W. J. T. Mitchell (Ed.), Landscape and Power. Chicago: University of Chicago Press.

[82] Snyder, J. (1994). Territorial Photography. In W. J. T. Mitchell (Ed.), Landscape and Power (p. 191). Chicago: University of Chicago Press.

[83] Krauss, R. (1982). Photography's Discursive Spaces: Landscape / View. Art Journal, 42(4), 311-319.

[84] Mitchell, W. J. T. (1994). Landscape and Power (p. 205). Chicago: University of Chicago Press.

[85] Greenberg, C. (1984). Art and Culture: Critical Essays, Boston: Beacon Press.

[86] Zukin, S. (1991). Disney World: The Power of Façade / The Façade of Power. In S. Zukin (Ed.J), Landscapes of Power: From Detroit to Disney World (pp. 217-250). California: University of California Press.

[87] Kojin, K. (1993). Origins of Modern Japanese Literature (B. Bary Tran.J. Durham: Duke University Press.

[88] Rendell, J. [2002]. Travelling the Distance / Encountering the other. In D. Blamey (Ed.J), Here, There, Elsewhere: Dialogues on Location and Mobility (pp. 43-54), London: Open Editions.

[89] Smith, J. (1993). The Lie that Blinds: Destabilizing the Text of Landscape. In J. S. Duncan \& D. Ley (Eds.), Place / Culture / Representation (pp. 78-92). London: Routledge.

[90] Hill, J. (2007). Introduction: Criticism by design. In Rendell, J., Hill, J., \& Fraser. M. [Eds.], Critical Architecture (p. 166). New York: Routledge.

[91] Forty, A. (2004). Words and Buildings: A Vocabulary of Modern Architecture. London: Thames \& Hudson.

[92] Corner, J.\& \& Hirsch, A. B. (2014). The Landscape Imagination Collected Essays of James Corner, 1990-2010. New York: Princeton Architectural Press.

[93] Corner, J. (1999). Eidetic Operations and New Landscape. In J. Corner (Ed.), Recovering Landscape: Essays in Contemporary Landscape Theory (p. 153). New York: Princeton Architectural Press.
[94] Steele, B. (2017). Anecdote as Evidence: Zaha's World. Log, (40), 27-31.

[95] Vesely, D. (1990). Drawing as a Vehicle of Creativity. Scroope, (2), 13-17.

[96] Corner, J. (1999). Eidetic Operations and New Landscape. In Corner (Ed.J, Recovering Landscape: Essays in Contemporary Landscape Theory (p. 154). New York: Princeton Architectura Press.

[97] Corner, J. (2006). Terra Fluxus. In C. Waldheim (Ed.), The Landscape Urbanism Reader (pp. 54-80). New York: Princeton Architectural Press.

[98] Hunt, J. D. (2013, October). Near \& Far, and the Spaces in Between. "Landscape Architecture of Tomorrow" International Conferences, Tsinghua University.

[99] Livesey, G. (Ed.) (2015). Deleuze and Guattari on Architecture: Critical assessments in Architecture (pp. 221-298). New York: Routledge.

[100] Corner, J. (1999). The Agency of Mapping: Speculation, Critique and Invention. In D. Cosgrove (Ed.), Mappings (pp, 213-252). London: Reaktion Book.

[101] Xu, B. (2015). My Real Words. Beijing: China Citic Press.

[102] Weller. R. (2001). Between Hermeneutics and Datascapes: A Critical Appreciation of Emergent Landscape Design Theory and Praxis through the Writings of James Corners 1990-2000. Landscape Review, 7(1), 11

[103] Tschumi, B. (1996). Architecture and Disjunction (p. 16). Cambridge: The MIT Press.

[104] Tate, A. (2015). Great City Parks (p. 60). New York: Routledge Press.

[105] Li, T. (2015). Where Is Snow Slide (p. 16). Beijing: China Citic Press.

[106] Rubio, I. S. (1997). Differences: Topographies of Contemporary Architecture (G. Thompson Tran.I. Cambridge: The MIT Press

[107] Li, O. P., \& Chen, J. H. (Ed.) (2000). Wandering between Modernity and Post-modernity (p. 214). Shanghai: Join Publishing.

[108] Kerby, K. (1923). An Old Chinese Garden: A Three-fold Masterpiece of Poetry, Calligraphy and Painting by Wen Zheng Ming. Shanghai: Chung Hwa Book Company.

[109] Girot, C. (2016). The Course of Landscape Architecture: A Natural History of Our Designs on the Natural World, from Prehistory to the Present. London: Thames \& Hudson.

[110] Krauss, R. (1982). Photography's Discursive Spaces: Landscape / View. Art Journal, 42(4), 311-319.

[111] Weller, R. (2001). Between Hermeneutics and Datascapes: A Critical Appreciation of Emergent Landscape Design Theory and Praxis through the Writings of James Corners 1990-2000 (Part one). Landscape Review, 7(1), 11. 